9-1992

\title{
Critical Theory and the Pragmatist Challenge
}

Dmitri N. Shalin

University of Nevada, Las Vegas, shalin@unlv.nevada.edu

Follow this and additional works at: https://digitalscholarship.unlv.edu/sociology_pubs

Part of the Politics and Social Change Commons, Social Psychology and Interaction Commons, and the Sociology of Culture Commons

\section{Repository Citation}

Shalin, D. N. (1992). Critical Theory and the Pragmatist Challenge. American Journal of Sociology, 98(2), 237-279.

https://digitalscholarship.unlv.edu/sociology_pubs/42

This Article is protected by copyright and/or related rights. It has been brought to you by Digital Scholarship@UNLV with permission from the rights-holder(s). You are free to use this Article in any way that is permitted by the copyright and related rights legislation that applies to your use. For other uses you need to obtain permission from the rights-holder(s) directly, unless additional rights are indicated by a Creative Commons license in the record and/ or on the work itself.

This Article has been accepted for inclusion in Sociology Faculty Publications by an authorized administrator of Digital Scholarship@UNLV. For more information, please contact digitalscholarship@unlv.edu. 


\title{
Critical Theory and the Pragmatist Challenge ${ }^{1}$
}

\author{
Dmitri N. Shalin \\ University of Nevada, Las Vegas
}

\begin{abstract}
Habermas's theory breaks with the Continental tradition that has denigrated pragmatism as an Anglo-Saxon philosophy subservient to technocratic capitalism. While Habermas deftly uses pragmatist insights into communicative rationality and democratic ethos, he shows little sensitivity to other facets of pragmatism. This article argues that incorporating the pragmatist perspective on experience and indeterminacy brings a corrective to the emancipatory agenda championed by critical theorists. The pragmatist alternative to the theory of communicative action is presented, with the discussion centering around the following themes: disembodied reason versus embodied reasonableness, determinate being versus indeterminate reality, discursive truth versus pragmatic certainty, rational consensus versus reasonable dissent, transcendental democracy versus democratic transcendence, and rational society versus sane community.
\end{abstract}

For much of the 20th century, pragmatism was perceived in Europe as a crude expression of Anglo-Saxon utilitarianism. Even thinkers sympathetic to the new American current found it inferior to the Continental philosophical tradition. Less charitable critics, such as the writers close to the critical theory circle, dismissed pragmatism as instrumental reason run amok, a technocratic decisionism severed from substantive-rational moorings. It was not until the 1960s that respectable European thinkers began to pay more favorable attention to pragmatism and its sociological counterpart, symbolic interactionism. A notable example is Jürgen Ha-

\footnotetext{
${ }^{1}$ This is a revision of a paper presented at the 85 th annual meeting of the American Sociological Association. I wish to thank participants in the Sociology Department Seminar at Boston University for helpful comments on an earlier draft of this article. The critical feedback from Mitchell Aboulafia, Thomas Alexander, Bob Antonio, Thomas Burger, Lewis Coser, Bruce Mazlish, Gene Rochberg-Halton, and Lon Shelby is also gratefully appreciated. Finally, I wish to thank the three $A J S$ reviewers for their comments and suggestions. Correspondence may be directed to Dmitri Shalin, Department of Sociology, University of Nevada, 4505 Maryland Parkway, Las Vegas, Nevada 89154.
}

(C) 1992 by The University of Chicago. All rights reserved. 0002-9602/93/9802-0001\$01.50

AJS Volume 98 Number 2 (September 1992): 237-79 
bermas, who recently admitted, "I have for a long time identified myself with that radical democratic mentality which is present in the best American traditions and articulated in American pragmatism" (Habermas 1985, p. 198). This statement is noteworthy not only because it holds fresh promise for a transatlantic dialogue, but also because it points to critical thinkers' renewed interest in liberal democracy and its emancipatory potential.

While the search for common ground will be welcomed on this side of the Atlantic, it will also raise some eyebrows. There are many points on which critical theorists and writers steeped in pragmatism appear to part company. The former have a penchant for totalities, are conversant with rationality at large, and have profound reservations about bourgeois democracy, whereas the latter attend to the particular, revel in multiple rationalities, and place much stock in democratic institutions. So, when Habermas (1986, p. 193) describes pragmatism as "a missing branch of Young Hegelianism," he is sure to make some critics wonder if his European biases blinded him to pragmatism's native roots.

I see nothing objectionable in the efforts to trace pragmatism's European lineage. Nor do I agree with those who think Habermas has gotten pragmatism all wrong. A movement as diverse as this lends itself to more than one reading, and Habermas does an important service by illuminating its various facets-most notably its political dimensionwhich American sociologists claiming the pragmatist legacy tend to ignore. Still, I want to take issue with Habermas because something is amiss in his analysis - the pragmatist sensitivity to indeterminacy, contingency, and chaos. This sensitivity is remarkably in tune with trends in modern science, and it deserves far closer attention from sociologists than it has been granted so far. It is my contention that taking objective indeterminacy seriously would require rethinking central conclusions in Habermas's theory of communicative action. In particular, I would like to show that Habermas elevated verbal intellect at the expense of noncognitive intelligence and thereby truncated the pragmatist notion of experience. I will also argue that incorporating the pragmatist perspective on democracy brings an important corrective to the emancipatory agenda championed by critical theorists.

Critical theory and Habermas have received a fair amount of attention (Jay 1973; Rose 1978; McCarthy 1978; Held 1980; Geuss 1981; Kellner 1985; Thompson and Held 1982; Antonio 1983; Bernstein and Forester 1985; Ferrara 1985; Benhabib 1987; Wolin 1987). Aside from Antonio (1989), however, few authors explored in depth the interfaces between pragmatism, democracy, and Habermas's thought, and none, to my knowledge, incorporated the pragmatist perspective on experience and explored its implications for Habermas's views. My discussion centers 
on the theory of communicative actions - a segment in Habermas's total corpus in which he joins issues with pragmatism and makes a concerted effort to incorporate its democratic ethos into the quintessentially European project of critical theory. I begin with the sources of critical theorists' ambivalence toward democracy. Next, I examine how Habermas merged the pragmatist and critical theory traditions. And finally, I subject his construction to criticism, using the pragmatist notions of experience, indeterminacy, and democracy as analytical tools.

\section{FROM CRITICAL IDEALISM TO CRITICAL THEORY}

It was not until Kant ([1781] 1966, p. xxiv) declared, "Our age is, in every sense of the word, the age of criticism, and everything must submit to it," that the term "critical" entered the philosophical lexicon in its modern sense. Kant chose his nomenclature deliberately to highlight the difference between the age of reason and the age of criticism, between overconfident rationalism of philosophes and "my transcendental or, better, critical idealism" (Kant [1783] 1950, p. 41). According to Kant, reason could no longer derive its mandate from divine inspiration or natural law but must lay its own standards for judging the true, the good, and the beautiful. For reason is not an outside observer impartially stating the truth and legislating a better future but a participant-observer whose rational activity gives the world its meaning and whose very unreflexivity breeds oppression. The objective structures one finds in the world, physical or social, are grounded in the a priori structures of the mind itself. To change the former, the subject has to grasp the latter. In other words, emancipation starts with self-reflection; only after reason has exposed its own prejudices and learned its own limits can it proceed with its appointed task. Hence, the endless exhortations by Kant's successors to do away with "the dogmatic tendency in man" (Fichte [1794] 1970, p. 161) and "dogmatism as a way of thinking" (Hegel [1807] 1967, p. 99) and get on with "a strenuous reacquisition of everything which has once been acquired" (Schelling [1800] 1978, p. 1).

These utterings sound vaguely subversive, but in the postrevolutionary climate of early 19th-century Europe they had a distinctly conservative ring to them. Anxious to avoid the bloody excesses of the French Revolution, critical idealists hastened to assure the world that the project of modernity they inherited from the Enlightenment would be carried out by peaceful means. The only force they were willing to tolerate was the force of reason itself-reason firmly grounded in principles, conscious of its moral moorings, and committed to the public good. This is what post-Kantian idealists called Vernunft and what they juxtaposed to Verstand, or everyday understanding, that, unbeknownst to itself, weaves 
the familiar world from its biases, preconceptions, and particularistic interests. Viewed from this angle, the battle for emancipation is but "the battle of reason . . . to break the rigidity to which understanding has reduced everything" (Hegel [1817] 1975, p. 53).

Vernunft is bound to strike some readers as an oversoul or a superhuman agency, but there is nothing especially mysterious about it. While the telos of reason is humanity as a whole, its locus operandi is the individual who speaks on behalf of reason. Society is fully rational when its members heed the claims of reason they have raised, when they act their conscience and submit to a tribunal within which one is simultaneously a defendant and a judge: "The consciousness of an inner tribunal in man . . . is conscience. . . . This original intellectual and . . moral capacity, called conscience, has this peculiarity, that although its business is a business of a man with himself, he is obliged by his reason to look upon it as carried on at the command of another person. For the transaction is here the conduct of a law-case . . . before a judge" (Kant [1803] 1904, p. 289).

The spirit of this statement is remarkably modern and democratic; it implies that every individual, regardless of origin or status, is a rational being and a potential agent of emancipation whose dormant capacity for criticism can be roused by the critical idealists' path-breaking intellections. Emancipation through reason transpires here as a project that humans qua rational beings accomplish by subjecting to critical analysis the a priori grounds for their conduct, freeing themselves from prejudices, and unswervingly following standards they have justified to themselves as universal, equitable, and humane.

The project of emancipation through reason came under attack during the reaction that followed the French Revolution, but its bourgeois democratic ethos continued to nourish the moral imagination well into the 19th century. This ethos was still palpable in the young Marx, who called for "a ruthless criticism of everything existing" ([1843] 1972, p. 8) and urged the "reform of consciousness [which] consists solely in letting the world perceive its own consciousness by awakening it from dreaming about itself, in explaining to it its own actions" ([1843] 1971, p. 82). Marx's commitment to emancipation through criticism, however, wore thin in the revolutionary climate of the time. By the mid-1840s, he began to doubt the peaceable route to emancipation and, along with other young Hegelians, set out to investigate what keeps reason from exercising its curative powers. The main impediment, Marx concluded, was class domination and the institutions, such as law, morality, and philosophy, through which the capitalist state obfuscates its oppression and perpetuates false consciousness among the toiling masses. The ruling class has the power to protect its particularistic interests, and it is naive to believe 
that it would bow to the voice of universal reason and agree to yield its power peacefully. Bourgeois democracy is a sham; its much-touted freedoms stand in the path of emancipation, insofar as they legitimize exploitation and prevent workers from understanding their role as a driving force in history. The real hope for emancipation lies with the concrete historical agent, the proletariat, a universal class for which criticism is not just a theoretical endeavor but a practical revolutionary deed. It is this class that can bring about communism - a society based on genuinely free discourse. Such a society frees consciousness from systematic ideological distortions, brings every rational individual into critical discourse, and thus for the first time makes reason truly universal and society fully rational.

The dilemma Marx bequeathed to his successors-Must reason rely on democratic procedures or class violence to achieve its emancipatory objectives? - informs many debates about critical theory in the 20th century. Few participants in these debates failed to acknowledge that "the critical theory is the heir of . . . German idealism" (Horkheimer [1937] 1976, p. 223). All agreed that critical theory aims at "the transformation of society [that] eliminates the original relationship between substructure and superstructure" (Marcuse [1937] 1968, p. 144; see also Marcuse 1960) and has as its ultimate goal "a society in which the 'people' have become autonomous individuals [freely] choosing their government and determining their life" (Adorno 1965, p. 105). How exactly these goals were to be accomplished, however, remained a contentious issue. The fact that bourgeois democracy had failed to forestall fascism in Europe seriously undermined the trust in liberalism's emancipatory potential. The disillusionment ran especially deep among the writers gathered around Horkheimer and the Frankfurt school, whose members sought to forge a conceptual link between totalitarianism and liberal rationalism. The impotence of bourgeois democracy is transparent in its surrender to totalitarianism, the kind that the Third Reich exemplifies most vividly. Indeed, "we can say that liberalism 'produces' the total authoritarian state out of itself, as its own consummation at a more advanced stage of development" (Marcuse 1968a, p. 19). "The pattern of all administration and 'personnel policy," according to Adorno ([1951] 1978, p. 131), "tends of its own accord . . . towards Fascism." Horkheimer (1978, p. 219) concurred with this diagnosis, charging that, left to its own devices, "democracy leads to its opposite-tyranny."

Critical theorists were aware that the United States did not fit neatly into this scenario, yet they convinced themselves that America was rapidly moving toward the "administered state," whose more subtle forms of domination bore equally ill tidings. The media-based domination they found in capitalist America looked every bit as pervasive, even if some- 
what more benign, as the one achieved in a totalitarian state. The cultural industry of capitalism works over time to produce mass consciousness suitable for the market economy and amenable to social control. Marcuse's (1964) One-Dimensional Man is the best-known account of the bondage in which reason finds itself in a capitalist society, although the basic insights articulated in this book had been familiar to critical theorists for decades (Horkheimer and Adorno [1944] 1989, p. 222).

While critical thinkers had few reasons to cheer European liberalism, they could not find much solace in the Marxist scenario either. For one thing, the proletarian masses failed to reveal themselves as the agents of historical emancipation Marx hailed them to be; rather, they displayed unmistakably conservative leanings and then precisely in the countries where "late capitalism" seemed to have reached its final stage. As the century unfolded, critical theorists also became painfully aware that the states claiming Marx's legacy had evolved their own totalitarianism, one that was equally inimical to critical theory's lofty ideals. Already in the 1920s, critical thinkers questioned Marx's thesis about "the universal class" and spurned Lukac's apology for communist party domination. After World War II, their disaffection for Marxist states and Left totalitarianism grew stronger (Neumann 1953, pp. 15-19; Marcuse 1958; Adorno [1966] 1973, p. 367; Horkheimer 1978, p. 230). Horkheimer expressed this indignation with particular force, sparing neither "the tendency toward fascism in capitalist states" nor "a sudden turn of leftradical opposition into terrorist totalitarianism" (1978, pp. 230, 233).

Marcuse was perhaps the only member of the original Frankfurt school willing to sanctify violence, to say that it was "a 'natural right' of resistance for oppressed and overpowered minorities to use extralegal means" (1965, p. 116). But his views did not sit well with the old-generation critical thinkers, who refused to endorse left-wing terrorism and student militancy. This refusal precipitated the split within the New Left, with the younger generation opting for radical action and the older one left wallowing in doubt about critical theory's practical import. "There certainly can be no true criticism without an intellectually grounded hope which derives its legitimacy from realistic possibilities," urged Horkheimer $(1978$, p. 138). Yet with the liberal path toward emancipation blocked by the market-driven media and with class warfare discarded as a viable alternative, it was precisely "an intellectually grounded hope" that critical thinkers found in short supply. After the Second World War in particular it became obvious to many observers that "Critical Theory was now incapable of suggesting critical praxis" (Jay 1973, p. 279). It was in this climate of uncertainty about the prospects for emancipation that critical theorists proclaimed the eclipse of reason and embraced Weber's prophesies about rationalization's crippling effect on democracy. 
What attracted Frankfurt school theorists to Weber was his unromantic view of reason as an agency whose power to control the world subverts human longing for meaningful life. This ironic capacity to render the world manageable and meaningless at the same time has been a central theme in emancipatory scholarship from the start. Already in his prizewinning Discourse on the Sciences and the Arts, Rousseau articulated the paradox of industry begetting poverty and culture breeding oppression. Critical idealists developed it further in their metaphysics of reason that remains estranged from itself and its products until it realizes its own responsibility for the world out there. Marx's theory, which blends the French Enlightenment and German idealism, offered another variation on this theme: history is the ongoing struggle of humanity to free itself from the dehumanizing consequences of its relentless drive to perfect the production forces-the drive that multiplies goods and miseries alike. These insights, minus the attendant optimism about reason's ultimate triumph, found their way into Weber's theory of global rationalization.

Reason's power to assert control, to increase efficiency, to calculate the future-to achieve any proximate goal-is designated by Weber as "instrumental" or "formal rationality." The capacity to judge value, to realize a higher purpose, to pursue a just cause-to lead a meaningful life-is termed "value" or "substantive rationality" (Weber 1964, pp. 184-86, 211-12). The relationship between the two is antinomian: the greater mastery reason achieves over the world of things and events, the less room is left for the questions of meaning and value; the more organized reason becomes internally, the narrower the scope for personal choice; the farther the state extends its bureaucratic procedures, the heavier its domination over the individual. A telling example is representative democracy, which purports to express the people's will but in fact subverts its professed goal by virtue of its complexity, its pervasive legalism, and its growing dependence on party leaders, who inexorably come to dominate politics. Democracy, Weber (1964, pp. 407-23) concluded, is the most efficient form of domination, all the more pernicious that it conceals its totalitarian proclivities under the veneer of bureaucratic rationality and popular rhetoric. The future of modernity is the "iron cage" that reason has unwittingly forged for itself and where it is destined to dwell-unfree, disenchanted, longing for meaning, unsure of its higher purpose (Weber [1904-5] 1958, p. 182). ${ }^{2}$

It is easy to see how much Critique of Instrumental Reason, One-Dimensional Man, or Negative Dialectics owes to this dark vision. Weber's unsentimental insights into the rationalization process and its unintended

\footnotetext{
${ }^{2}$ For further discussion of Weber's views on formal and substantive democracy see Giddens (1972), Mommsen (1974), and Cohen (1985).
} 
systemic consequences have been absorbed into such critical-theoretic concepts as the "administered state," "totalitarian democracy," "expert cultures," "isolation through communication," and "media-distorted discourse." His disdain for formal democracy seems to have been borne out by actual historical developments in the capitalist West and the communist East. And his skepticism about the prospects for substantive democracy neatly rationalized the Frankfurt school's failure to tie its theory to political practice. There was a penalty, of course, that critical theorists had to pay for embracing Weber-surrendering rational hope for emancipation. This was what "melancholy science," as Adorno dubbed critical theory, was coming to. And this was why Jürgen Habermas found the Frankfurt school's confines too narrow and moved beyond its fold. He did it to take a fresh look at the question that the old-generation critical thinkers left unanswered: Is emancipation through reason a rational hope? Habermas's Theory of Communicative Action can be seen as an attempt to invigorate critical theory by merging the Continental and Anglo-Saxon traditions and bringing the pragmatist perspective to bear on the project of emancipation through reason.

\section{FROM CRITICAL THEORY TO COMMUNICATIVE ACTION}

"It is only in Western nations that the precarious and continually threatened achievements of bourgeois emancipation and the worker's movement are guaranteed to any extent worth mentioning. . . . And we know just how important bourgeois freedoms are. For when things go wrong it is those on the Left who become the first victims" (Habermas 1986, p. 42). This intriguing observation illuminates a paradox: the very fact that the Institute for Social Research, the hotbed of critical thinking, has been thriving in capitalist West Germany seems to suggest that it serves the existing order. This contradiction has not been lost on the right- and left-wing critics, who alternatively charged the Frankfurt school leaders with ingratitude toward the existing order or betraying working-class interests. In their defense, critical theorists pointed to the marginal position they occupy in the academe, the media's power to blunt the critical message, and the false consciousness pervading capitalist society, yet these explanations are rather half-hearted, given the prominent positions that critical theorists acquired in German academia after World War II, and they certainly do not go to the heart of the matter. The real problem is that "the old Frankfurt School never took bourgeois democracy very seriously" (Habermas 1986, p. 98). By contrast, Habermas takes pains to emphasize that academic freedom is for real, that bourgeois democracy is a major historical accomplishment, and that its liberal institutions are indispensable for genuine criticism. All this by no means obviates the 
fundamental criticism that critical theorists have leveled against the capitalist order, most signally against "the pervasive inequality of freedom [and] unequal opportunity of access to the means of democratic persuasion" (Marcuse [1968] 1976, p. 326). Habermas accepts the premise that the rationalization process has produced systemic consequences highly injurious to the democratic process: modern systems are unmanageably complex; a consumerist economy manufactures false needs; the mass media manipulates public opinion; expert cultures obfuscate the public's stake in technical issues; and relentless bureaucratization robs humans of their autonomy, dignity, and solidarity (Habermas [1962] 1989, pp. 141-222; [1981] 1987b, pp. 332-73). These are the familiar ills of late capitalism. Formidable though they are, they do not spell democracy's impending doom. The old-school critical theorists have grown unreasonably pessimistic about the project of modernity, but their pessimism is historically unfounded and theoretically fallacious; the prospects for emancipation through reason "can today no longer be disqualified as simply utopian" (Habermas 1989, p. 235). The agenda for the day is "the reconciliation of a modernity which has fallen apart," the rededication to the idea "that without surrendering the differentiation that modernity has made possible in the cultural and economic spheres, one can find forms of living together in which autonomy and dependency can truly enter into a non-antagonistic relation, that one can walk tall in a collectivity that does not have the dubious quality of backward-looking substantial forms of community" (Habermas 1986, p. 125). To salvage the project of modernity, critical theory must cure the democratic process of distortions it suffers in a capitalist society. How can this be done? Habermas answers with a prescription borrowed from American pragmatism: by mobilizing the public, revitalizing public discourse, and getting personally involved in politics.

Habermas's willingness to join issues with pragmatism is very much at odds with the German tradition, in which the intellectual was "bred in the veneration of theory and history, and contempt for empiricism and pragmatism" (Neumann 1953, p. 19). Frankfurt school thinkers were solidly embedded in this tradition, their writings evincing little appreciation for pragmatism's emancipatory potential (Marcuse 1939/1940; Horkheimer 1937, 1947). They dismissed pragmatism in a wholesale fashion as "the abasement of reason" and "a genuine expression of the positivistic approach," a philosophy which advocates the "reduction of reason to a mere instrument" and serves as a "counterpart of modern industrialism, for which the factory is the prototype of human existence, and which models all branches of culture after production on the conveyor belt, or after the rationalized front office" (Horkheimer 1947, pp. 45-54). Habermas's break with this tradition was not instantaneous. According 
to his own account (Habermas 1986, pp. 104, 151, 193), his interest in pragmatism goes back to the early 1960s, when Karl-Otto Apel encouraged him to read Peirce and other pragmatists. Knowledge and Interest, published in Germany in 1968 (Habermas 1971; see also Habermas 1975), is the first work in which Habermas treats pragmatism systematically. There is no mention of Mead in this volume, Dewey is cited once or twice, but Peirce is treated at length as a representative pragmatist thinker. The treatment is more sympathetic than the one accorded by Marcuse and Horkheimer, but it does not break completely with the thesis, first advanced by Max Scheler ([1926] 1977), that pragmatism exemplifies a formal-rational preoccupation with nature that undermines the normative discourse embedded in substantive rationality. What Habermas (1986, p. 193) finds appealing in Peirce is the "logical socialism" implicit in the latter's exalted view of a community of rational thinkers engaged in critical inquiry and ceaselessly advancing toward the truth through uncoerced discourse, rational argumentation, and consensus building. It was not until Habermas encountered Dewey and Mead, however, that he fully realized the momentous implications that Peirce's ideas had for critical theory.

"The radical-democratic branch of Young Hegelianism" is the term Habermas (1986, p. 151) coined to frame the pragmatism espoused by Dewey and Mead. This apt description highlights the often overlooked debt that pragmatist thinkers owe to German idealism, the ingenuous manner in which Peirce, Dewey, Mead, and to a lesser extent, William James developed a Hegelian concern with language, communication, and intersubjectivity - the social dimension of reason. Dewey's writings were particularly instrumental in sensitizing Habermas to the continuity between scientific inquiry and democratic discourse, to the fact that "freedom of inquiry, toleration of diverse views, freedom of communication, the distribution of what is found out to every individual as the ultimate intellectual consumer, are involved in the democratic as in the scientific method" (Dewey 1939, p. 102). From the same source comes Habermas's appreciation for the public and its role in sustaining inquiry into communal affairs. The prospect for democracy, Dewey contended and Habermas agreed, "rests upon persuasion, upon ability to convince and be convinced," upon "the improvement of the methods and conditions of debate, discussion and persuasion. That is the problem of the public" (Dewey $1916 a$, p. 134; 1939, p. 102). Taking the argument one step further, Dewey (1946, p. 132) comes up with an appeal that critical theorists would have appreciated, if not fully endorsed: "Humane liberalism in order to save itself must cease to deal with symptoms and go to the causes of which inequalities and oppressions are but the symptoms. In order to endure under present conditions, liberalism must become 
radical in the sense that, instead of using social power to ameliorate the evil consequences of the existing system, it shall use social power to change the system."

Mead caught Habermas's attention for some of the same reasons that Dewey did, but in addition to Mead's progressive democratic agenda, Habermas found in his writings a theory that "elevated symbolically mediated interaction to the new paradigm of reason" and that signified a major advance beyond the old "paradigm of the philosophy of consciousness" (Habermas 1984, p. 390). This point, crucial to Habermas's own project, deserves some elaboration. We can recall that critical idealists placed much stock in the historical process that elevates biased, unreflexive, everyday understanding (Verstand) to the loftier status of selfconscious reason that spearheads criticism and attends to higher truths (Vernunft). Habermas traces this trust in the noble faculties of reason to the tradition that stretches from Descartes, through German idealism, to critical theorists. The problem with this tradition, as Habermas sees it, is that it does not incorporate the sociological perspective on reason as a communicative affair; instead, it treats reason as a unitary phenomenon modeled after instrumental labor activity, as a process bound to the subject, who confronts the world all alone and single-handedly transforms it into a rational objective whole. Hegel's objective idealism did entail some tantalizing insights into the role that language and community play in the genesis of self-consciousness, but much of his work followed the old paradigm, and whatever sociologically relevant ideas he had presaged failed to take root on German soil. ${ }^{3}$ By contrast, American pragmatists seized exactly this neglected aspect of German idealism, expanding it into a new paradigm of reason as social through and through. Sidestepping the familiar pair of Verstand and Vernunft, the new paradigm gives prominence to Verständigung, the interactive process of reaching understanding. "The change in perspective from solitary rational purposiveness to social interaction," writes Habermas (1987a, p. 149), "does promise to illuminate the very process of mutual understanding [Verständigung] - and not merely of understanding [Verstehen]." Mead, Habermas continues, resolutely renounced the paradigm of reason as solitary consciousness and went further than other contemporary scholars to lay out the paradigm of reason as communicative action and to spell out its implications for the emancipatory agenda, which is why Mead's

\footnotetext{
${ }^{3}$ Habermas may be underestimating the extent to which the social dimension of reason was elaborated in the German tradition in general and in transcendental idealism in particular. For an alternative view, see Royce (1919, p. 65), Mead (1936, p. 147), and Shalin $(1986 a, 1986 b)$.
} 
ideas must be included in any theory that assigns to self-consciousness and critique a role in social reconstruction.

Indeed, Mead not only joins in the classical discourse on rationality and emancipation through reason-he also pushes it in a new direction. His discussion owes much to German idealism, which Mead studied as a student at Harvard and in Berlin and then taught for many years at the University of Chicago. ${ }^{4}$ His views on evolution as a process that brings nature to self-consciousness and assures humans "some degree of control of the process of evolution out of which they arose" (Mead 1938, p. 511) bring to mind Hegel's phenomenology, with its dialectics of reason that objectifies itself in nature, finds itself estranged from its own products, and then gradually rediscovers its authorship over the way things are. But Mead's approach is also thoroughly informed by the evolutionary perspective and the pragmatist determination to tie thinking to conduct. "What I have attempted to do," explains Mead (1934, p. $334)$, "is to bring rationality back to a certain type of conduct, the type of conduct in which the individual puts himself in the attitude of the whole community to which he belongs. This implies that the whole group is involved in some organized activity and that in this organized activity the action of one calls for the action of the other organisms involved. What we term 'reason' arises when one of the organisms takes into its own response the attitude of the other organisms involved. . . When it does so, it is what we term 'a rational being." "Reason is historically embedded in communal existence; once brought into being, it transforms community life itself, for, according to Mead, "when the process of evolution has passed under the control of social reason" (1938, p. 508), it "becomes not only self-conscious but also self-critical" (1934, p. 255). From a central preoccupation with the mastery over things, reason now turns toward the questions of value. To use Weberian terminology, reason becomes substantive; that is, it reevaluates values, rationally resolves social conflicts, and endeavors to revamp the entire social order from which it sprang:

The rational solution of the conflict, however, calls for the reconstruction of both habits and values, and this involves transcending the order of the community. A hypothetically different order suggests itself and becomes the end in conduct. . . . In logical terms there is established a universe of discourse which transcends the specific order within which the members of the community may, in a specific conflict, place themselves outside of the community order as it exists, and agree upon changed habits of action and a restatement of values. Rational procedure, therefore, sets up an order within which thought operates. . . . Its claims are the claims of reason. It

\footnotetext{
${ }^{4}$ See Joas (1985) and Shalin $(1984,1990)$ on the Mead-idealism connection.
} 
is a social order that includes any rational being who is or may be in any way implicated in the situation. [Mead (1930) 1964, p. 404]

A cursory look at Habermas's theory reveals the measure of his debt to pragmatism. We find in his work the same mixture of historical optimism that harks back to critical idealism and tough-minded realism found in Progressive Era pragmatism. The belief in "a noncoercively unifying, consensus building force of a discourse in which the participants overcome their at first subjectively biased views in favor of a rationally motivated agreement" (Habermas 1987a, p. 315) is combined here with a keen awareness that communications remain "systematically distorted" in a "money-bound," "media-steered" society that keeps public discourse from realizing its full critical potential (Habermas 1987b, pp. 256-82). In spite of these instructive continuities, there are several issues on which Habermas and pragmatists part company. I shall come back to the pragmatist critique of Habermas in the next section; here I consider the points for which Habermas takes pragmatists to task.

From the sociological standpoint, pragmatism's central contribution is to an "action-theoretic" framework. Symbolic interactionists have explored at length the linguistically mediated interactions in which human identities are formed, and thereby they have expanded our understanding of the communicative foundations of life worlds. At the same time, pragmatism-inspired social theory has little to offer to "system-theoretic" approaches, Habermas insists. It ignores the normative underpinnings of society, its functional needs as a system, and it cannot satisfactorily explain how communicative distortions and social oppression are generated and reproduced. Thus, Mead assumes the normative status for his notion of the "generalized other" without explaining where its power to control behavior comes from. Similarly, Dewey is too sanguine about democratization's by-products - expert cultures and administrative procedures, which are as endemic to modern democracy as they are subversive of its substance. "We want democratization," Habermas (1986, p. 67) intones, "not so much in order to improve the efficiency of the economy as to change the structures of power: and in the second place to set in motion ways of defining collective goals that merely administrative procedures or power-oriented decisions would lead astray or cripple."

It is arguable whether pragmatism lacks normative dimension, let alone whether it is inherently incapable of dealing with structural phenomena, but it is fair to say that system-theoretic issues have not been central to pragmatist analysis in the past. To offset this limitation of classical pragmatism, Habermas seeks to complement it with ideas from several other sources. From Weber, he borrows his insight into the differentiation of value spheres; from Durkheim, the notion of normative con- 
straint; from Parsons and Luhmann, a version of systems theory. From Austin, Wittgenstein, and Searle, he appropriates the theory of speech acts, and from Kohlberg and Piaget, the genetic theory of moral growth. Combining these ideas with the Meadian theory of symbolic interaction, Habermas formulates his theory of communicative action (TCA), with its conceptual core-cuniversal pragmatics." Habermas uses the term "pragmatics" in a different sense than Peirce, who saw in it a branch of cosmology dealing with signs in their natural settings, or Charles Morris, who used the term to designate a part of semiotics that explicates the relations between symbols and their users. The pragmatics that Habermas has in mind is "universal"-it purports to unveil most general standards that govern rational communications in human discourse. Drawing on Weber's theory, Habermas isolates three basic forms of discourse or value spheres that become progressively autonomous in the course of historical rationalization: theoretic/scientific, moral/practical, and expressive/aesthetic. Communications within each of these domains revolve around a peculiar validity claim: theoretic discourse concerns the truth of our propositions, practical discourse bears on the justice of our actions, and aesthetic discourse highlights the sincerity of our feelings. Although these validity claims are intertwined with scientific, moral, and artistic discourses, they are not bound exclusively to these specialized value spheres. In our everyday life, we routinely assert facts, appeal to norms, and claim to be sincere; that is, we raise and settle validity claims concerning truth, justice, and authenticity, and, by doing so, we continuously reproduce our normative, cultural, and private worlds. In the language of speech act theory, we "do things with words" via "performative actions," which are linguistic facts just as they are social facts. Now, the crucial point Habermas makes is that the validity claims remain largely unthematized in everyday transactions, during which they are redeemed not so much by recourse to reasons and arguments as through strategic action and appeal to custom. It is the task of universal pragmatics to render these unreflexive validity claims problematic, to help settle them by rational means. Universal pragmatics articulates "a procedural concept of rationality," "a pragmatic logic of argumentation" (Habermas $1987 a$, p. 314), and promises to certify "the rationality of process of reaching understanding" (Habermas 1985, p. 196). Its main premise is that any communicative act aimed at reaching understanding contains implicit, context-free, and imminently social standards that must be met if its outcome is to be judged rational. The situation where such standards are fully met is called "ideal speech situation."

Habermas does not provide a glossary of rules underlying the ideal speech situation. Nor does he offer any final formulation, as he continues to revise the theory he first outlined in the late 1960s (see, e.g., Habermas 
1970, 1979). Still, I think these procedural rules or guidelines for achieving communicative rationality can be codified as follows:

1. An ideal speech situation provides every interested individual a chance to participate in discourse and argue one's viewpoint.

2. It is free from coercion, domination, and power play-all purely instrumental and strategic motifs.

3. It differentiates cognitive, normative, and expressive validity claims implicit in our assertions and redeems them through arguments alone.

4. It makes a freely reached consensus the sole foundation for democratic will formation and policy articulation.

5. It leaves a rationally motivated agreement open to revision in light of further deliberations.

The thing that strikes one immediately is how well these stipulations jibe with the critical idealists' belief in Vernunft as "the true tribunal for all disputes of reason [which] secures to us the peace of a legal status, in which disputes are not to be carried on except in the proper form of a lawsuit" (Kant 1966, p. 486). The continuity does not escape Habermas, who grounds his theory on the "principle, that-expressed in the Kantian manner-only reason should have force" (Habermas 1970, p. 7). At the same time, Habermas is quick to point out that his theory is not to be confused with transcendental idealism. Universal pragmatics presupposes certain standards for rationality and serves as a measuring rod for judging concrete communicative practices, yet its validity is not entirely a priori. Procedural standards for rationality spelled out in universal pragmatics are counterfactual: "One should not imagine the ideal speech situation as a utopian model of an emancipated society" (Habermas 1986, p. 90). Nor should an ideal speech situation be confused with an ideal type, for the latter professes ethical neutrality whereas the former is self-consciously normative and prescriptive. Universal pragmatics is the case of "reconstructive theory" (Habermas 1979, pp. 8-9, 178-79); that is, theory whose normative thrust does not preclude empirical validation, even if it can be achieved only indirectly. Taking his clues from Durkheim's writings on the sacred and Piaget-Kohlberg's research on moral growth, Habermas infers that the movement toward communicative rationality is both an evolutionary trend, evident in the shift from sacred to discursive practices, and an ontogenetic current, manifest in the gradual increase in the individual's capacity for moral reasoning. At the heart of modernity is the empirically observable drive toward rationalization, which gradually replaces "the weight of tradition with the weight of arguments, . . . an attitude of faith based on the authority of a doctrine with a theoretical attitude" (Habermas 1979, p. 113), and it is this relentless drive that pulls society away "from the sacred founda- 
tions of legitimation to foundation on a common will, communicatively shaped and discursively clarified in the political public sphere" (Habermas $1987 b$, p. 81). This shift, most apparent in the history of the Occidental world, can be gleaned from the gradual gain in human rights, the emergence of the independent judiciary, the separation of cognitive and power claims, the strengthening of voluntary associations, and similar developments that mark the movement, however contradictory, toward communicatively rational forms of legitimation.

Bureaucratization, juridification, mediatization, and such like systemic dysfunctions point to another, less benign facet of rationalization. Subjected to the capitalist market imperatives, these developments produce distortions that undermine communicative rationality and weaken public discourse. As each value sphere evolves according to its own logic, it becomes insular, impregnable to considerations from other value spheres: technical issues are separated from moral concerns; ethical demands are severed from expressive needs; personal agendas come into conflict with public ones. The mass media further exacerbates these trends by making a spectacle out of public discourse, turning it into an entertainment: 'Discussion, now a 'business,' becomes formalized; the presentation of positions and counterpositions is bound to certain prearranged rules of the game; consensus about the public matter is made largely superfluous. . . . Critical debate arranged in this manner fulfills important socialpsychological functions, especially that of a tranquilizing substitute for action" (Habermas 1989, p. 164). Now, it needs to be stressed that the problem for Habermas is not modernity and rationalization as such, but fractured modernity and one-sided rationalization, and the cure is breaking the walls that separate value spheres without destroying an insight peculiar to each. The question, in other words, is how to "bring viewpoints of moral and aesthetic critique to bear-without threatening the primacy of questions of truth" (Habermas 1987b, p. 398). If this can be done at all, it is through public discourse, by painstakingly redeeming the validity claims implicit in our communications and following the rules of procedural rationality elucidated in the universal pragmatics. One hundred percent procedurally rational communications may be impossible to achieve, but by opening up the legitimation process to all members of society and verbalizing norms previously immune to rational adjudication, we, at the very least, assure movement in the right direction. Take the ideal speech situation seriously, Habermas advises, rid yourself of hidden agendas and avail yourself of procedurally rational discourse, and you help bring about an emancipated society, a democracy that is substantively rational. "The false alternative set up by Max Weber, with his opposition between substantive and formal rationality, is overcome" (Habermas 1987a, p. 315). 
Most commentators agree that TCA constitutes an important advance, or certainly a new beginning, for critical theory. This advance has not come cheaply. In some respects, Habermas's theory was a step backward (e.g., Habermas does not show Adorno's sensitivity to the indeterminate and the irrational). In settling old issues, Habermas has raised new, sometimes even more vexing ones. Is reason genderless and classless? Does it have to shed its ethnic, racial, religious, cultural, and personal colors before it can do its critical job? How can theoretical, practical, and aesthetic discourses inform each other without losing their vital autonomy? What about contingency and indeterminacy thwarting our best plans and good faith efforts? Is the lack of rational consensus a sign that communicative action has failed? These are just some of the questions that TCA has stirred up and that have generated a voluminous literature. ${ }^{5}$ I shall try not to repeat the more obvious criticisms voiced in the past, and, in keeping with my objectives, confine my comments to the issues on the interfaces of pragmatism, democracy, and critical theory.

\section{FROM COMMUNICATIVE ACTION TO PRAGMATIC POLITICS}

The ideal speech situation outlined in Habermas's universal pragmatics is more than a prescription for successful communication. Enciphered in its principles is a blueprint for a rational society - a society whose members make good sense, offer rationales for their action, mean what they say, and practice what they preach. This lofty image, which brings to mind the ancient quest for a way of life combining truth, justice, and happiness, has undeniable appeal. It is also flawed in several respects. My critique is sympathetic, for I share Habermas's humanistic agenda, yet it is principled because I question some of his fundamental premises. My discussion draws on the pragmatist ideas left out in Habermas's analysis, and it is organized around the following themes: disembodied reason versus embodied reasonableness, determinate being versus indeterminate reality, discursive validity versus pragmatic certainty, rational consensus versus reasonable dissent, transcendental democracy versus democratic transcendence, and rational society versus sane community. It should be noted that I do not try to picture pragmatism as a monolithic movement free from internal contradictions and inconsistencies. However, the present reconstruction centers on pragmatists' shared concerns,

\footnotetext{
${ }^{5}$ A wide range of critical comments on Habermas's corpus can be found in two representative collections: Habermas: Critical Debates, edited by Thompson and Held (1982), and Habermas and Modernity, edited by Bernstein (1985). For a more detailed discussion of Habermas's theory of communicative action see McCarthy (1978), Ferrara (1985), Benhabib (1987), Antonio (1989), and a special issue of Symbolic Interaction (Shalin 1992).
} 
and especially on their common stance against rationalism, the vestiges of which can be found in Habermas's thought. ${ }^{6}$

\section{Disembodied Reason versus Embodied Reasonableness}

My first objection concerns the place Habermas assigns to reason in relation to nature and human body. Reason appears in TCA primarily as thinking (consciousness, understanding, cognition). It has no obvious relation to the human body and noncognitive processes (emotions, feelings, sentiments). What pragmatists call "experience" has shriveled into verbal intellect, which assumes in TCA a privileged position as a locus of rationality. Communicative competence is predicated on reason's capacity to be "relieved of the pressure of action and experience" (Habermas 1984 , p. 25), to "transcend all limitations of space and time, all the provincial limitations of the given context" (Habermas 1987b, p. 399). Rational discourse, correlatively, deals in ideas, concepts, and reasons rather than in sentiments. The latter represent an inferior species of intelligence, in that they have limited generalizability, cannot be readily communicated, are inherently uncritical, and need to be edified by intellect. To the extent that noncognitive elements enter discourse, they have to be grasped conceptually and measured by theoretically grounded standards, a process that certifies our emotive life as authentic and sincere. Affects that do not pass the test set up by reason are deemed "irrational" and subjected to "therapeutic critique," which helps the individual "free himself from illusions, and indeed from illusions that are based not on errors (about facts) but on self-deceptions (about one's own subjective experiences)" (Habermas 1984, p. 21).

By contrast, pragmatists caution against the "hypostatization of cognitive behavior" (Rorty 1982, p. 201) and warn that consciousness "is only a very small and shifting portion of experience" (Dewey 1916b, p. 6). "Reason, anyway, is a faculty of secondary rank," Peirce (1976, p. xxi) remarks, "cognition is but the superficial film of the soul, while sentiment penetrates its substance." What is important for the pragmatist is that cognitive behavior belongs to a larger context of material practice, which philogenetically and ontogenetically antedates mind's conceptual faculty. Communication is contingent on minding something together, carrying out a larger act in which participants are engaged bodily as well as mentally. "Mental processes imply not only mind but that somebody is minding" (Mead 1938, p. 69). "The mother minds her baby; she cares

\footnotetext{
${ }^{6}$ Among contemporary works on pragmatism, I found particularly useful the following: Alexander (1987), Bernstein (1983), Coughlan (1975), Joas (1985), Kloppenberg (1986), Rockberg-Halton (1986), Rorty (1979, 1982), and Rosenthal (1986).
} 
for it with affection. Mind is care in the sense of solicitude, anxiety, as well as of active looking after things that need to be tended" (Dewey [1934] 1958b, p. 263). Pragmatists refuse to isolate communicative actions from this larger context, from "the universe of nonreflectional experience of our doings, sufferings, enjoyments of the world and of one another" (Dewey 1916b, p. 9). Notice that the pragmatist maxim-knowing is doing-brooks no anti-intellectualism. Pragmatists do not deny the key role abstraction and generalization play in theoretical discourse, nor do they dispute that private interests and crude emotions can distort reasoning. Nevertheless, pragmatists argue, the "conclusion is not that the emotional, passionate phase of action can be or should be eliminated in behalf of a bloodless reason. More 'passions,' not fewer, is the answer. . . Rationality, once more is not a force to evoke against impulse and habit. It is the attainment of a working harmony among diverse desires" (Dewey [1922] 1950b, pp. 195-96). Pragmatists are quick to point out that "reasoning has no monopoly of the process of generalization," that "sentiment also generalizes itself" (Peirce 1976, p. xxi). Feelings can be universalized and communicated even more readily than ideas. We share attitudes before we share thoughts (Mead 1934), we sympathize before we understand (Benhabib 1987), we feel other people's pain before we know its source (Rorty 1989). Habermas shows little appreciation for such nondiscursive communication. He elevates the cognitive form of universality above all others and in the process inadvertently devalues human experience as merely private and intellectually mute. This indifference to the nondiscursive element in culture, to the fact that just "as the body becomes 'encultured,' . . . so culture becomes 'embodied" (Alexander 1987, p. xix), is a vestige of rationalism and its notorious tendency to think in dichotomies, such as subject and object, reason and nature, sentiment and intellect, and so on. Pragmatists, on the other hand, are convinced that noncognitive prehensions have an intelligence all their own, which a radically theoretical attitude tends to ignore or, worse, suppress. Contrary to the rationalist view, reason has a lot to learn from noncognitive functions: feelings point to a crisis in experience, sentiments signal when general principles take a beating from obdurate reality, emotions provide a running commentary on the success of our plans. To divest reason from living experience is to disembody it, to leave it helpless in the face of the perennial indeterminacy and contingency with which humans have to struggle in their everyday existence. When thinking leaves experience far behind and escapes into theoria, it is likely to lead practical action astray.

I am not trying to ascribe to Habermas an untenable view that feelings and emotions are inherently irrational and need to be suppressed in favor of pure reason. He is also right when he says that some of our sentiments 
are systematically distorted and have to be subjected to therapeutic critique. My point is rather that TCA leaves out from its purview the noncognitive forms of intelligence irreducible to verbal intellect, what pragmatists call "embodied" or "concrete reasonableness" (RochbergHalton 1986; Alexander 1987). Reasonableness is minding embedded in practical activity and embodied in emotionally charged situations. It does not scoff at common sense or Verstand, and it resists Vernunft's imperious tendency to subordinate other faculties to its dictate. Knowledge uninformed by feelings and stripped of emotive elements can be rational without being reasonable; it achieves certainty by discarding insight from the senses in favor of the rationales laid out by the intellect. Yet, even though both noncognitive experience and speculative thought partake in the world, the former is embedded in nature more immediately, yielding instant information about the changing situation through its affective states vital to the organism: "Experience is of as well as in nature. [It] reaches down into nature; it has depth. It also has breadth and to an indefinitely elastic extent. It stretches. That stretch constitutes inference" (Dewey [1929] 1958a, p. 4a). "The continuum which [sentiment] forms instead of being like that of reason merely cognitive, superficial, or subjective . . penetrates through the whole being of the soul, and is objective or to use a better word extant, and more than that is existent" (Peirce 1976 , p. xxi). Reason's access to the world, by contrast, is mediated by a feeling body, whose testimony certifies our validity claims. It is in the Platonic domain that reason reigns supreme, the domain where objects are not contaminated by impurities besetting the mundane realm and obey laws prescribed by pure reason. As long as reason stays within this rarefied chamber, it can abstract from concrete situation and take a profitable leave of one's emotional investments, but as soon as knowers step into the world of uncertainty, they inexorably fall back on an auxiliary intelligence about things themselves that only noncognitive faculties can gather. Human intelligence is emotional just as emotions are intelligent, and this is so because we live in the world of indeterminacy that no rational faculty and theoretical rigor can expunge.

\section{Determinate Being versus Indeterminate Reality}

The residual place Habermas assigns to body and noncognitive experience is consistent with a rationalist ontology. This ontology paints an overdeterminate picture of the universe as factual, internally structured, determined prior to the knower's engagement in it, and marked by "the categorical distinctions between the objective, social, and subjective worlds" (Habermas 1987 b, p. 159). The early and relatively undifferentiated worldviews (those centered on mythology or religion) tend to blur the 
distinctions between these three worlds and the validity claims peculiar to each. Knowledge appears in such worldviews as a mixture of the objective and the subjective, the particular and the general, the cognitive and the emotional, with no sharp line drawn between verifiable facts, culturally sanctioned dogma, and patently idiosyncratic claims. The modern - scientific-outlook allows one to separate verifiable facts from commonly held illusions and makes possible, at least in principle, the rational adjudication of conflicts in the normative sphere. Purified by proper method from unwarranted preconceptions, ideological obfuscations, and personal biases, public discourse yields a rationally motivated consensus about facts in our shared universe and points to the most rational course of action.

Twentieth-century pragmatist ontology has come to us bearing different labels- "pluralism," "perspectivism," "objective relativism," and more recently "new fuzziness" (Rorty 1989, p. 51). Yet its basic insight is essentially the same: "Uncertainty does not belong simply to the values, it belongs to the facts as well" (Mead, n.d., b8, $f 1)$. "Any view which $^{7}$ holds that man is a part of nature, not outside it," according to Dewey (1946, p. 351), "will certainly hold that indeterminacy in human experience, once experience is taken in the objective sense of interacting behavior and not as a private conceit added on to something totally alien to it, is evidence of some corresponding indeterminateness in the process of nature within which man exists (acts) and out of which he arose." The pragmatist ontology pictures a universe vastly different from the one envisioned by classical rationalism, "a universe which is not all closed and settled, which is still in some respects indeterminate and in the making, . . . an open universe in which uncertainty, choice, hypotheses, novelties and possibilities are naturalized" (Dewey [1927] 1950c, p. 52). Such a universe is full of uncertain outcomes that defy our best efforts to reduce chaotic processes to a theoretical scheme in which all effects have identifiable causes and our destiny submits to rational manipulation. Pragmatist philosophy "gives us a pluralistic, restless universe, in which no single point of view can ever take in the whole scene" (James [1897] 1956, p. 177). "Man lives in a world of surmise, of mystery, of uncertainties," admonishes Dewey (1958b, p. 198), “'Reasoning' must fail man." Again, it is easy to misconstrue these musings as a sign of anti-intellectualism, but the point is not that rational knowledge is impossible or useless, but that rationalists underestimate the contingency en-

\footnotetext{
${ }^{7}$ Mead (n.d.) refers to the George H. Mead papers gathered in the Special Collections Department of the Joseph Regenstein Library at the University of Chicago. The letters $b$ and $f$ followed by a number indicate the box and folder, respectively, in which a particular document is located.
} 
demic to the world, and they vastly exaggerate reason's capacity to marshal it as an orderly flow of objective being.

What is to be stressed here is that we are dealing not with residual indeterminacy reflecting the limits of our current knowledge but with "objective uncertainty" and "indeterminate reality," the emergent universe in which "deliberation and choice are determining factors" (Dewey $1950 b$, p. 310). It is up to concrete reasoning-always an interest-bound, socially anchored, situationally specific undertaking - to lift the world from its natural state of indeterminacy and turn it into a meaningful, manageable, semiorderly whole. This objective whole maintains its predictable properties insofar as we sustain our interest in it, as long as our determined collective efforts last. Each time we pass judgment on the situation at hand-literally terminate indeterminacy — we bring out some of its potentialities and render obscure its other possible determinations. An act of doing justice, which a theoretical, normative, or aesthetic judgment aspires to be, is thus inevitably an act of doing violence. Just as it opens one horizon of meaning it closes an indefinite number of alternative determinations (fittingly, "to terminate" means to extinguish, to put an end to, as well as to bring into focus, to frame in definite terms). Whatever determinacy we encounter in the world is, consequently, of our own making. We terminate indeterminacy in deed and in situ, using terms supplied by a community, and we do so as participant-observers who are part and parcel of the situation we seek to comprehend: "If there were no human beings (or comparable sentient creatures) there would be no situations in nature" (Gouinlock 1972, p. 8). The knower's embeddedness in the world as a participant-observer has far-reaching epistemological implications, none more important than this: validity claims about the world of uncertainty cannot be settled through argument in the propositional discourse; the redemption of validity claims is a pragmatic endeavor accomplished via social intercourse.

\section{Discursive Validity versus Pragmatic Certainty}

One of the pillars on which Habermas founded TCA is his "consensus theory of truth" (Habermas 1973, p. 19; 1984, pp. 8-42). We can speak more broadly about the discursive theory of validation, for all validity claims, including rightness and sincerity, are at issue. This theory stipulates that validity claims must be redeemed through arguments and that "communicative actors can achieve an understanding only by way of taking yes/no positions on criticizable validity claims" (Habermas 1984, p. 70). If "reasons that force us to take a rationally motivated position of yes or no" (Habermas 1985, pp. 194-95) failed to produce a consensus, a communicative action has missed its stated end; such failure signifies 
that the participants lacked candor to carry out communicative action to its rational conclusion. One notable exception allowed by discursive theory of validation involves aesthetic discourse: "The claims to sincerity connected with expressive utterance is [sic] not such that it could be directly redeemed through argument as can truth or rightness claims. . . . The sincerity of expressions cannot be grounded but only shown; insincerity can be revealed by the lack of consistency between an utterance and the past or future actions internally connected with it" (Habermas 1984, p. 41). No extradiscursive means are allowed into theoretical and normative discourses, where participants are compelled toward a rational consensus by methodically advancing well-formed propositions, by clarifying the internal logic of the argument, and by adjudicating conflicts through theoretical means.

While TCA attends to discursive validity vouchsafed through propositional formal logic, pragmatist theory focuses on "pragmatic certainty" (Rosenthal 1986, p. 59), which requires joined action and logistical reasoning as much as argumentative skills. Discursive validation is part of a larger human practice where all ideational objects have their roots. There are no objects to perceive, to value, to abstract from, according to pragmatists, until there has been the "full completion of the act" or "consummation" (Mead 1938, p. 23). The world that lends itself to objective judgment is already an objectified world, reality transformed by our perception, cognition, and collective action, and to say that our thought is true to this world makes as much sense as to say that this world is true to our preconceptions about it. Either way, to be certain about our claims, we have to engage in collective transformative action. Pragmatists are at one with Marx on this: "The question whether objective truth is an attribute of human thought-is not a theoretical but a practical question" (Marx [1846] 1963, p. 197). That is to say, there is more to redeeming truth claims than finding good reasons and building consensus about them. We need to be certain that the predicated identity between knowledge and reality can be actually redeemed, and that means immersing oneself in the situation, joining in a collective act, and carrying it to a completion.

A word of caution against setting up a false dichotomy between practically reached certainty and communicatively established consensus is called for: one is meaningless without the other. The pragmatist critique presented here aims at redressing the balance. Rational arguments have been advanced in favor of releasing mentally ill patients who pose no immediate threat to themselves and to the public, and a solid public consensus was built around this issue in the 1960s. Yet this perfectly rational policy turned out to be a failure, as the logistics of providing for the ex-patients' needs via neighborhood communities proved to be much 
too formidable for the effective delivery of noninstitutional care. The moral here is that we cannot always redeem substantive claims-we cannot be certain about their pragmatic merit-in advance of staking our action on their truthfulness or, for that matter, justness and sincerity (the premise equally applies to theoretical, normative, and aesthetic discourses). The pertinent question for pragmatists is not whether a proposition is true according to some intrinsic rationality, but whether the real situation can be shaped according to a stated rationale. To find out how consensually validated terms mesh with reality, we have to move beyond symbolic and performative action; we must try to terminate extant indeterminacy (or reterminate established determinacy) through practical social intercourse. Truth is no longer grasped here in the rationalist manner as adequatio intellectus et rei but instead is pragmatically conceived as a practically accomplished unity of knowledge and reality. In this reckoning, it makes as much sense to inquire whether an action-transformed situation is true to our concepts as to ask whether our propositions correspond to objective reality. To accomplish pragmatically the predicated unity of knowledge and reality, the knower has to engage in what interactionists call "joint action" (Blumer 1969, p. 17). This region, situated on the intersection between labor and discourse, has no conceptual footing in TCA. And yet, this is a domain of the utmost importance, the realm of everyday living and minding together where theoretical, normative, and aesthetic discourses merge into one, where humans feel, think, and transact at the same time, and where a different logic is called upon to help us master everyday contingencies. ${ }^{8}$ The pragmatist logic is the logic in use; it stipulates that reality does not always lend itself squarely to yes/ no judgments and allows practical knowers to say "perhaps," "it depends," "who knows," and to use other indeterminate truth values that help us handle situational indeterminacy. The dilemma that so struck William James ([1909] 1967, pp. 208, 207)—“either [I] give up my intellectualistic logic, the logic of identity . . . or, finally, face the fact that life is logically irrational"-is familiar to every practical knower who had to contend with everyday indeterminacy in the pluralistic universe and who could conclude, with James, that "logic being the lesser thing, the static incomplete abstraction, must succumb to reality, not reality to logic" (1967, p. 207). Binary logic favored by rationalist thought is replaced in pragmatism by the logic in use, also known as the logic of inquiry or the logic of situation. This pragmatist logic signals a break

\footnotetext{
${ }^{8}$ Various attempts have been made to conceptualize this intermediate space. Durkheim searched for it in the intraprofessional type interactions, as did Parsons, and Peter Burger detected it in the realm of communal, familial interactions. See David Sciulli $(1988,1992)$ for an overview of the issues involved.
} 
with "the rationalism's disdain for the particular, the personal, and the unwholesome" (James 1967, p. 309). It stipulates that judgment is "in" this world as much as it is "about" it, that "the proposition is itself a factor in the completion of the situation" (Dewey 1916b, p. 338), and it attends to "the transformation of an indeterminate unsettled situation into a determinate unified existential situation" (Dewey 1938, p. 296). The quest for rational truth and moral rightness is supplanted here by the quest for warranted assertability and practical certainty. Whereas the former depends on discursive validation and "comparing ready-made ideas with ready-made facts," the latter requires pragmatic inquiry and presumes that "both idea and 'facts' are flexible, and verification is the process of mutual adjustment, of organic interaction" (Dewey [1890] 1969, p. 87). The quest for pragmatic certainty sensitizes the knower to fuzzy things, multiple realities, semichaotic systems, and it favors participant-observation as a practical way to fathom objective uncertainty. The radically pragmatic epistemological stance also entails clear ethical and political implications: it counsels tolerance to ambiguity, calls for personal responsibility, and encourages rationally motivated dissent.

\section{Rational Consensus versus Reasonable Dissent}

My next criticism concerns TCA's emphasis on consensus and its disregard for the constructive properties of dissent. On several occasions, Habermas (1979, pp. 1, 92) qualifies as "normal" situations and communications that are "largely conflict free." Consensus appears to be communication's raison d'etre. This is certainly true in an ideal speech situation where "all participants pursue illocutionary aims without reservation in order to arrive at an agreement that will provide the basis for a consensual coordination of individually pursued plans of action" (Habermas 1984, pp. 295-96). The broader the consensus, the greater the rationality. Anything that falls short of universal consensus is, on this premise, less than fully rational. Discourse ethics demands that those partaking in rational discourse should be motivated by the "intention of convincing a universal audience and gaining general assent for an utterance" (Habermas 1984, p. 26). Anybody who refuses to join in an emerging rational consensus, spurns communicatively certified reasons, or stops short of trying to convince all other participants of the merit of one's proposition violates the norms of discourse ethics. The spirit of communicative action militates against accepting conflict as a normal part of the communication process and dissensus as a rational product of action aimed at reaching understanding. "To be sure," Habermas (1985, p. 194) admits, "it is also a characteristic of modernity that we have grown accustomed to living with dissent in the realm of questions 
that admit of 'truth'; we simply put controversial validity claims to one side 'for the time being.'" Dissent about truth claims, in other words, is more an expediency than a principled stance in a communicatively shaped situation; in the long enough run, dissent must yield to rational consensus.

Pragmatist ontology and epistemology suggest a different approach, one that accentuates the limits of theoretically grounded consensus and highlights the productive properties of dissent. "Real possibilities, real indeterminations, real beginnings, real ends, real evil, real crises, catastrophes, and escapes, a real God and a real moral life, just as common sense conceives these things, may remain in [a radically pragmatic] empiricism which that philosophy gives up an attempt either to 'overcome' or to reinterpret in monistic form" (James 1956, p. ix). The universe so conceived belies TCA's consensual bias. The inexhaustible possibilities of being hidden in its depths can hardly be fathomed through a thin-gruel theoretical consensus. It is as if we choose to understand Bach by reading the music sheets rather than by listening to his fugues. Communication at the level of formal notation is what Habermas seems to propose in order to ferret out the communication's rational content. Yet the score is not the only thing that counts in music; each recital offers a dissenting yet valid interpretation or rather improvisation (just think about the vastly different communication that takes place when Vladimir Horowitz, Glenn Gould, Bella Davidovich, or the Modern Jazz Quartet interprets Bach). The pluralistic universe envisioned by pragmatists encourages dissent, warrants a wide margin of uncertainty, and invites caution toward policies based on purely theoretical calculations.

Habermas's universal pragmatics leaves hardly any room for the honest difference of opinion. A disagreement that refuses to go away is taken here as a sign of a failure, and a moral one at that: it hints at a strategic motif at work and/or betrays a weak communicative resolve. By grounding a rational consensus in sound reasons, Habermas also finds himself saddled by an awkward implication that whosoever refuses to abide by the communicatively established consensus is, by definition, less than fully rational. In the pragmatist reckoning, there is no necessary relationship between procedural rationality and substantive consensus. Public discourse is as much about consensus building as it is about fostering dissent. In pragmatist theory, by contrast, dissensus and consensus are accorded an equally prominent theoretical role. The proper function of communicatively achieved consensus is to designate reasons sound enough to merit pragmatic validation. A freely achieved consensus is usually partial, imperfect, provisional; it does not obviate the need for conflict, it legitimizes conflict as an inalienable part of rational discourse. 
Nor does communicative action merely tolerate dissent, it encourages dissent as vital to the community's well-being. Dissent is the first sign that communication was uncoerced and that participants expressed themselves freely. It is in the countries where the speech situation is far from ideal that consensus is commonly forged and dissent becomes exceptional. What makes the dissenting attitude rational is the realization that various lines of argumentation can be meritorious, that the situation lends itself to more than one adjudication, that the attendant risks and uncertainties are great, and that the widest possible consensus is bound to break down the moment we set out to implement it.

All this should not be taken to mean that discursive consensus has no practical value. I am not trying to attribute to Habermas an untenable position that dissent does not matter. It is also true that some basic ground rules must be agreed upon before we can dissent in a meaningful and productive manner. Still, I feel that Habermas does not make nearly enough of rationally motivated dissensus, nor does he explore the practical consequences of dissent with which we must square off once we have agreed to disagree. Rational consensus, like a generally accepted moral rule, is but "a tool for analyzing a specific situation, the right or wrong being determined by the situation in its entirety, and not by the rule as such" (Dewey and Tufts [1908] 1976, p. 302). We cannot play chess without agreeing on rules, nor drive a car without knowing traffic signs, nor live in a community without following social conventions, yet we routinely disagree about the best chess move, the safest response to an emergency, or a just solution to a social problem, and the more complicated the situation, the more room there is for the honest difference of opinion. This goes not only for common folks unschooled in hermeneutics but also for well-seasoned experts (think about split decisions handed down by the U.S. Supreme Court). Being at odds with oneself, being of two (or more) minds on a given issue, is a distinctly human and imminently rational sentiment. We call it "ambivalence," and we find it especially handy in dealing with the muddled situations that surround us on all fronts, most signally moral situations, which rarely submit to general principles. "Every moral situation is a unique situation," pragmatists contend (Dewey [1920] 1950a, pp. 132-33): "The primary significance of the unique and morally ultimate character of the concrete situation is to transfer the weight and burden of morality to intelligence." The key word here is "intelligence" - the pragmatist name for reason firmly embedded in a concrete situation, fully in touch with its feelings, and mindful of the uncertainties and risks involved. Such embodied reason has a modern temper that befits democracy, and the "gospel of uncertainty" (Kloppenberg 1986, p. 413) it brings into the project of 
modernity offers an important corrective to the emancipatory agenda championed by classical and contemporary critical theory.

\section{Transcendental Democracy versus Democratic Transcendence}

Although the index for Habermas's monumental study does not mention the term, TCA is very much a treatise on democracy or rather a critical examination of its perversion in modern society. According to Habermas, whose views on the subject go back to 1962 and his Habilitationsschrift (1989), the capitalist welfare state subverts the substance of the democratic process through bureaucratic procedures and mediatized communications which, on the one hand, bring more people into the public sphere than any other political system, but on the other, emasculate that sphere by whittling down its participatory substance. Late capitalist society stifles "the possibilities for spontaneous opinion formation and discursive will-formation through a segmentation of the voter's role, through the competition of leadership elites, through vertical opinion formation in bureaucratically encrusted party apparatuses, through autonomized parliamentary bodies, through powerful communication networks, and the like" (Habermas 1987b, p. 365). Communicative action is bound to be distorted under these quasi-democratic conditions, and a manufactured consensus is likely to be false as long as capitalist market imperatives constrict various social strata's access to and participation in public affairs. Characteristically, Habermas does not cite the incurably formalistic logic of rational administration that critical theorists have singled out as the culprit. The gist of the problem, for Habermas, is the disuse, misuse, and abuse that the public sphere has fallen into under certain historical conditions. He believes that these conditions can be rectified and ameliorated through critical inquiry into our communicative practices. Such inquiry falls within the domain of "transcendental hermeneutics" or "transcendental pragmatics" (Habermas 1979, p. 23), which offer "a reconstructive analysis oriented to general and unavoidable presuppositions" and reveal "structures of mutual understanding that are found in the intuitive knowledge of competent members of modern societies" (Habermas 1987b, p. 383). Now, the crucial point in the whole argument is that the a priori conditions for reaching understanding explicated by transcendental (or universal, as Habermas now prefers to call it) pragmatics are fundamentally the same as the conditions for achieving a democratic society. This is already evident in the rational procedures guiding communicative action. These procedures, encoded in the ideal speech situation, can be read as prescriptions for substantive democracy or "democratic form of decision-making, namely: rationalizing decisions in such a way that they can be made dependent on a consen- 
sus arrived at through discussions free from domination" (Habermas 1970). ${ }^{9}$ Notice that substantively rational decisions cannot depend on opinion polling, electioneering, and vote counting because such mechanisms of formal representation transfer individual's discursive rights to others and succeed chiefly in "a cleansing of political participation from any participatory content" (Habermas 1987 b, p. 350). Formally democratic decisions and collective actions based on them are marred by nondiscursiveness and thus are communicatively flawed, which is why "majority decisions are held [in TCA] to be only a substitute for the uncompelled consensus that would finally result if discussion did not always have to be broken off owing to the need of a decision" (Habermas 1970, p. 7). A communicatively sound social order must be based on a rationally motivated, freely achieved universal consensus, which simultaneously satisfies the transcendental conditions for successful communicative action and for a genuinely democratic society.

There is much in the above argument that dovetails with, if not derives from, pragmatism. Pragmatists acknowledge that modern societies produce systemic consequences and have functional implications detrimental to the participatory ideal. Long before Habermas they thought that "discontent with democracy as it operates under conditions of exploitation by special interests has justification" and warned that "the functional aspect is contradictory to the ends of democracy" as long as "there is the opportunity for exploitation of the individual" (Dewey 1946, p. 133; Mead 1934, pp. 288-89). Since the onset of the Progressive Era, pragmatists stressed that "no government by experts in which the masses do not have the chance to inform the experts as to their needs can be anything but an oligarchy managed in the interests of the few" (Dewey [1927] 1954, p. 208). Habermas's vision of a communicatively sound social order is also adumbrated in pragmatism, which treats democracy as a form of communication, "a name for a free and enriching communion" (Dewey 1954 , p. 184), and trusts humans to resolve their differences by discovering common goods. "Reason is then a medium within which values may be brought into comparisons with each other, in abstraction from the situations," reads a particularly Habermasian passage in Mead ([1930] 1964, p. 406), "and within this impartial medium it becomes possible to reconstruct values and our conduct growing out of them." In spite of these instructive continuities, there are several points on which Habermas and pragmatists diverge.

${ }^{9}$ The term substantive democracy is used here in a broad sense that is consistent with Habermas's vision of a communicatively sound democratic system that is rich in participatory content and, as such, contrasts with the notion of formal democracy, in which individuals are deprived of a meaningful opportunity to engage in communicative action. 
Pragmatists are not satisifed with discursive elucidation of common values and universal principles; "the universe of discourse," they are likely to stress (Mead, n.d., b8, $f 8$ ), "is rather the universe of intercourse" - the latter brings to a test the precepts furnished by the former. "The ethical problem is always a specific one," says Mead (1964, p. 405), "the problem itself defines the values." "Especially does the pragmatist deny that the solution of our problems can be found in any vision given on the mount or prearranged order of society" (Mead, n.d., Addenda, $b 3, f 7)$. Universal pragmatics does not exactly envision a prearranged order, but its procedural strictures are too general, too far removed from messy things out there to help us navigate in the world of uncertainty. The theory of communicative action goads us toward consensus and demands the unequivocal commitment to certain policies even before we have a chance to find out whether they pass muster in life. Only immersion into the practical world, with all its hazards, confusions, and unforeseen developments, can clarify what a given consensus means, which reality it engenders. Habermas (1973, p. 19) misses this point when he disparages the pragmatist rush to action and praises the virtues of discursive situations "which transcend the compulsions of action." Pragmatists do not deny reason its proper rights - they want to subject its pronouncements to pragmatic test. Truth is a practically accomplished unity of knowledge and reality, and that means tinkering with things and events to make sure they match our theoretical calculations. In the process, we are certain to run into unforeseen circumstances, unanticipated consequences, and unyielding particulars, which need to be transcended in situ and not just in theoria. As chaos theory tells us, minor changes in one variable can have vast ramifications for a system as a whole. This applies to human societies as well, which evolve patterned ways of handling indeterminacy.

If society is a semiordered chaos routinely generating unanticipated consequences, as pragmatism implies, then democracy is a historically specific mode of managing uncertainty. "Democracy expects the unexpected" (Betz 1974, p. 216) and "recognizes that uncertainty is inevitable and then turns it to positive account" (Dewey and Childs 1933, p. 309; see also Przeworski 1986). Democratic systems thrive on uncertainty; they rely on market, competition, ad hocing, and muddling through as necessary, even if distortion-prone, mechanisms for handling a large number of incalculable variables. By the same token, democratic polities promote conflicting life-forms, open up public discourse for an everwidening range of participants, and maximize the public's role in defining the terms in which indeterminacy can be legitimately terminated. Contrariwise, nondemocratic polities seek to expunge uncertainty through exhaustive planning, centralized control over terminological practices, 
and punitive actions against dissenters who favor alternative terminologies. The less democratic the system, the more it fears discord and values consensus and the more likely it is to favor a monopoly on the terminological means of production of social reality as objective and meaningful. This is why pragmatists do not accept consensus, however discursively achieved, as the highest democratic value. The pluralistic universe presupposed by pragmatist thought precludes any one standpoint from being anointed as unassailably true, good, and authentic. If any claim merits such honorific title, it is the agreement to disagree, without which a democratic process is indeed unthinkable. Democratic institutions give extra room for the honest difference of opinion, maximize opportunities for dissent, not just for consensus, and protect minorities from aspersions the majority is apt to cast on their rationality. Dissenting insights may be rejected by the community, and for good reasons, yet they are to be safeguarded because they hint at the unrealized potentialities of being.

To be sure, democratic societies fall short of their professed ideal of the unlimited access to public discourse and allow assorted elites an undue influence over public affairs, but this is a poor reason to discount nondiscursive means in politics. When we vote, select representatives, delegate authority to experts, and vest power in the executive branch, we admittedly move away from democratic discursiveness and thereby open the door for the kind of distortions Habermas so eloquently decries. But without these formal means we could not break the discursive impasse or react efficiently to situations that require prompt action. If we take discourse ethics seriously, we should keep on arguing until a universal consensus has emerged, lest our good faith efforts are put into question. Yet such demands are unrealistic. They are certain to run afoul the hung jury predicament and founder on the kind of problems Rousseau faced when he tried to reconcile volonte general and volonte de tous in his proposal for direct democracy (see Schumpeter 1950, pp. 235-68; Van den Berg 1990, p. 163). From the pragmatist standpoint, the fact that participants resort to a show of hands and settle for a less than universal consensus is no affront to reason. Majority decision serves as a democratic, if formal, device for reaching a working consensus about conflicting rationalities vying for practical validation. To test a rationality means not only going beyond communication but also assuming responsibility for our action - not just discursive action but also a joint act, which has practical consequences and which presupposes a different type of ethics than the ethics of discourse.

The pragmatic ethics (I shall call it the "ethics of uncertainty") urge close attention to the "correlation between the means used and the consequences that follow" (Dewey 1946, p. 138). Attention to consequences produced by our conduct is mandatory because different lines of action 
incur varied risks and beget unpredictable, irreversible outcomes. Rational people disagreed as to whether we should have relied on economic sanctions to force Saddam Hussein from Kuwait, but once the decision was made to forge ahead with the military option, consequences befell the innocent and the guilty alike. The Lithuanian government's bid for independence was well grounded in "good reasons," yet it produced a bloody backlash few people were able to foresee. No matter how discursively validated a policy is, responsibility for the consequences should be borne by the individual. The ethics of democracy are the ethics of responsibility, and, as such, they contrast with the ethics of good faith and ultimate ends, which seek to suppress uncertainty and narrow the scope for individual judgment.

It would be unfair to say that Habermas somehow endorses the ethics of ultimate ends - his writings on German politics belie any such accusation. Nor does he subscribe to the utopian vision of Jacobin democracy that imposes its will on the unwilling subjects. And yet in its implications, Habermas's ethics are not free from some of the difficulties faced by the moral systems based on good faith and end-rational grounding. Discursive ethics plead for a domination-free life, forswear force other than the force of reason, and aim at substantive democracy, yet the results are likely to be ironic. Reason cannot escape domination as long as it seeks to impose on the world an overarching rationality in the face of the ample evidence that things themselves do not suffer theory gladly and are sure to spoil our best-faith efforts. A consensus compelled by no other force than that of good reasons is still a forced consensus if it chains the individual to a predetermined rationale, situational contingencies notwithstanding. And transcendental democracy is likely to remain a utopian trap if it does not make room for personal responsibility. By digging the communicative foundations of a rational social order, Habermas gave the critical-theoretic program a much-needed lift, yet his communicatively grounded reason still needs to be enlightened to fulfil its emancipatory promise. It needs to be guarded against its own intolerance and maximalism. It needs ambivalence, common sense, compassion-the virtues of intelligence that pragmatists consider central to democratic transcendence and sane existence in the world of uncertainty.

\section{Rational Society versus Sane Community}

Habermas shares with classical critical theory its predilection for "democratization, decentralization and socialist positions," yet his agenda is different from the one implicit in the Frankfurt school, for he respects liberalism, appeals directly to the public, and "demands a remoralization of politics" (Habermas 1986, p. 71). All systemic distortions, according 
to TCA, are prefigured in the communicative domain. If social organization has turned oppressive and politics have collapsed into administration, it is because our transactions have grown communicatively irrational. With the community as a whole losing control over society's steering mechanisms, special interests seize the opportunity to assert their particularistic rationalities under various ideological covers. Repackaged for mass consumption, these (ir)rationalities are translated back onto the individual plane. Here, through the mechanisms of consumption and socialization, they are bred into actors' bones, producing distorted needs and mentalities that, in turn, help reproduce impersonal bureaucracies and oppressive institutions. The system has uncoupled itself from the private sphere; it has stripped humans of their dignity, usurped their autonomy, perverted their needs-it has colonized the life world. To reclaim control over the system, the community must cut bureaucracy down to size, symbolically as well as literally, and recreate the conditions somewhat akin to the intellectual salons of the Enlightenment, where men and women gathered to make sense together and to furnish intellectual insights that would later be felt throughout society. The task for our time is to open the political forum to the public at large, refocus attention on communicative action, and radically upgrade the quality of the processes aimed at reaching understanding: "The reevaluation of the particular, the natural, the provincial, of social spaces that are small enough to be familiar, of decentralized forms of commerce and differentiated public sphere - all this is meant to foster the revitalization of possibilities for expression and communication that have been buried alive" (Habermas $1987 b$, p. 395). The communicative sphere must be freed from distortions, and that means taking seriously our assertions about facts, becoming reflexive about the normative bonds that we forge through our performative actions, making a personal commitment to be sincere. We have to learn to speak to ourselves and others in the voice of reason. Herein lies hope for "the possibility of settling our disagreements by adducing reasons," of releasing the "emancipatory potential built into communication structures themselves" and achieving a communicatively "rational society" (Habermas 1987b, pp. 74, 390).

Once again, we can see how well Habermas's "communicative socialism" (O'Neill 1985, p. 59) fits in with the pragmatist agenda and how much his specific program veers away from it. Pragmatists agree with Habermas that bureaucratized social systems should be scaled down and made accountable to the public. "Democracy must begin at home, and its home is the neighborly community" (Dewey 1954, p. 213). Like Habermas, pragmatists believe in the "passing of functions which are supposed to inhere in the government into activities that belong to the community" (Mead 1899, p. 369). "The most concrete and fully realized 
society is not that which is presented in institutions as such," contends Mead ([1915] 1964, pp. 166-67), "but [in] the readjustments of personal interests that have come into conflict and which take place outside of court, in the change of social attitude that is not dependent upon an act of legislature." But look at the values pragmatists praise in the communicatively shaped order: "The community values of friendship, of passion, of parenthood, of amusement, of beauty, of social solidarity in its unnumbered forms" (Mead 1964, p. 311). This is not exactly the list you find in TCA. The two perspectives share broad objectives but differ in significant details.

Habermas wants to clear communications from inarticulate sentiments, private interests, logical inconsistencies, and similar distortions as inimical to reason. Pragmatists find these essential to keeping one's sanity amidst the semichaotic order that surrounds us in everyday life. Pure reason has always looked with suspicion at passion and sentiment, but it has never succeeded in purging itself from their invidious touch. Reason has shown itself to be intolerant of ambiguity, contemptuous of common sense, disdainful of compromise, proud of its intellectual machismo in dealing with particulars, and arrogantly dismissive of its own blunderings in the practical domain. History is filled with records of human enterprises bearing reason's seal of approval and stoking nothing but bitter ironies: revolutions that abuse human rights in the name of humanity; laissez-faire liberalism that spawns monopolies under the banner of free trade; centralized economies that excel in producing shortages under the aegis of the plan; welfare programs that create a permanent underclass under the pretext of giving the underprivileged a fair chance - the list goes on and on. Habermas (1987a, p. 310) has a point when he sees the problem "not as an excess but as a deficit of rationality," but then he may be too kind to pure reason. He is certainly a bit disingenuous in his critique of "Western 'logocentrism" " given his own failure to acknowledge intelligence native to instinct and common sense. Deracinated affect is a dangerous thing, but reason that plugs its ears to elude the siren voices of sentiment runs equally great risks. Cultures that have mindlessly entrusted themselves to the guidance of pure reason and "undercut instinct, common sense, and the reasonableness of sentiment" have insured their own "imminent extinction at the hands of unhinged reason" (Rockberg-Halton 1986, p. 144). "Motivation through 'good reasons"" (Habermas 1979, p. 200) does not forestall the emergence of the bureaucratic "megamachine" that devours its creators (Mumford 1967). Pushing body, instinct, and sentiment to the life world's periphery does not make culture more humane (Alexander 1987). And as Dewey acutely sensed, abstract thought that shuns the senses and ignores the ordinary betrays its insensitivity in practical affairs. 
Men who devote themselves to thinking are likely to be unusually unthinking in some respects, as for example in immediate personal relationships. A man to whom exact scholarship is an absorbing pursuit may be more than ordinarily vague in ordinary matters. Humility and impartiality may be shown in a specialized field, and pettiness and arrogance in dealing with other persons. . . . "Reason" as a noun signifies a happy cooperation of a multitude of dispositions, such as sympathy, curiosity, cooperation, exploration, experimentation, frankness, pursuit-to follow things throughcircumspection, to look about at the context, etc., etc. [Dewey 1950b, pp. 198, 196]

To guard against its own excesses, reason must be enlightened by feeling, edified by emotions, ennobled by desire. Above all, it must be sensitized to objective uncertainty. Coming to grips with the nondiscursive element in our experience not only helps safeguard reason from overindulging in abstractions but also opens the door to creativity and social reconstruction. Habermas appears to overlook this point when he commits himself to "the cognitivist position" that social problems can be solved within the domain of Verständigung, strictly "by way of argumentation" (Habermas 1984, p. 19). For their part, pragmatists accentuate the role of intuitive impulses and appeal to artistic imagination as powerful tools for breaking the routines of experience, smashing barriers that separate groups, and generating fresh insights into troublesome social issues (Dewey 1958b). "To the degree that we make the community in which we live different we all have what is essential to genius," explains Mead (1934, p. 218). Social creativity involves "those values which are found in the immediate attitude of the artist, the inventor, the scientist in his discovery, in general in the action of the ' $I$ ' which cannot be calculated and which involves a reconstruction of society, and so of the 'me' which belongs to this society" (Mead 1934, p. 214). Social change is predicated here not just on the linguistically mediated "me" as it makes an appearance in discursive communication but on the instinctive, aesthetic, unpremeditated "I" that bursts forth on the social scene and makes individual experience valuable to the community as a whole.

Seen from this pragmatist angle, values appear inseparable from habit, instinct, and behavior; they are "valuations, habitualized acts of judgment rather than simply inert norms" (Rochberg-Halton 1986, p. 16). Social norms have to find their way into mind's noncognitive recesses and become suffused with emotions, transformed into habits, translated into routine judgments: "No social modification, slight or revolutionary can endure except as it enters into the action of a people through their desires and purposes" (Dewey and Childs 1933, p. 318). Humane community is first and foremost an attitude shared by its members, a feeling like empathy or solidarity generalized to a point where it can inform social routines. Such nondiscursive communications endemic to commu- 
nal being are not to be equated with diminished rationality. "Another meaning of 'rational' is, in fact, available. In this sense, the word means something like 'sane' or 'reasonable' rather than 'methodical.' It names a set of moral virtues: tolerance, respect for the opinion of those around one, willingness to listen, reliance on persuasion rather than force" (Rorty 1987 , p. 40). ${ }^{10}$ The last point hints at broadening communicative action to include rhetoric and suasion. Communicative, or rather communal, actions need not be a zero-sum game, in which my being in the right means you are in the wrong. Communal living requires tolerance to contradictions, a state that TCA proscribes as "a sign of a more irrational conduct of life" (Habermas 1984, p. 61). Inconstancy and paradoxicality are endemic to the pluralistic universe, to the "big, buzzing confusion" that James discovered at the core of our being. This universe is composed of many verses and is shot through with competing perspectives. It allows reason to be scattered across disparate social niches; it makes it appear under jarring sexual, racial, ethnic, religious, cultural, and social guises; it does not demand that various life-forms be brought to a common denominator other than their proponents' commitment to coexist peacefully, respect each other's uniqueness, and, where possible, draw on experience accumulated by others. As such, the pluralistic universe serves as the epitome of modernity pragmatically understood.

The pragmatist outlook on modernity is closer to Simmel than to Weber in that pragmatists find modernity distinguished by the expansion of the meaningful domain rather than its contraction, the unfettering of reason rather than its encagement, the revitalization of the life world rather than its disenchantment. The pluralistic universe does present the modern individual with the mind-boggling question of how to wade through jangling possibilities and keep one's sanity intact, yet pragmatists see this situation less as a threat than a promise, insofar as it makes for a more meaningful life-as in life full of meaning (James 1956, pp. 184-215). Today's pragmatists feel no compulsion to transform this semirational/semiabsurd world into a unified, logical, communicatively purified, perfectly transparent block universe. To deal with modern life's chaotic cross-currents, they cultivate "irony," aim for "a de-theoreticized sense of community," and "take seriously Dewey's suggestion that the way to reenchant the world, to bring back what religion gave our forefathers, is to stick to the concrete" (Rorty 1985, p. 173).

This modest program has several practical implications. For one thing, it suggests that not every evil and irrationality can be communicatively

${ }^{10}$ The pragmatist argument presented here overlaps with Gadamer's (1977) critique of Habermas for his indifference to the constructive, creative role that tradition plays in furthering communal values and living. 
exorcised-some are endemic to human conditions and are best dealt with through joint narrative, communal grieving, shared muteness, bracketing, and glossing over. The pragmatist stance implies that universalizing the feeling of empathy and compassion is at least as important for sane existence as staking and redeeming validity claims. It calls for irony, humor, and ambivalence in handling many an absurdity of everyday life (Rorty [1989, p. 61] has a point when he calls Habermas a liberal without irony, for just as any other virtue, earnestness can be carried too far). Pragmatism also has a clear political dimension. It has been historically aligned with progressive reforms aimed at systemic distortions that limit access to public discourse, the most insidious among these distortions being economic deprivation (Faris 1970; Deegan and Burger 1978; Diner 1980; Shalin 1988). At the same time, politics in the pragmatist key is rather ideologically atonal. Laissez-faire market, nationalized economy, industrial growth, entitlement programs-these are but means to make our communal being more reasonable and sane, and if the results prove to be other than expected, pragmatists do not hesitate to acknowledge as much and to try other means. Critics have variously spurned this stance as conservative, radical, or opportunistic, but it defies any partisan label.

Above all, pragmatists call for personal efforts in one's immediate community. In this respect, they follow Chekhov's counsel to avoid grandstanding and take up small deeds. That is to say, pragmatism challenges us to start with ourselves, become reasonable with those closest to us, get out to a town meeting, PTA gathering, neighborhood association, and try to body forth a better community by talking, humoring, and cajoling its members into more reasonable ways. Once our efforts are met with success in our own abode, they are likely to be noticed and to fire up action elsewhere. As the Progressive Era pragmatist reformers had learned, social reconstruction starts in one community, envelops the city, moves to the state level, and then comes to the national legislature. The scheme does not fit each case and every country alike, but it suggests the kind of pragmatic, grass-root politics essential to democratic reconstruction. As long as we are willing to exert ourselves on behalf of our own community, pragmatists urge, we make the burden of living more bearable for all and keep alive the hope for emancipation through reason that critical theory has clung to since Rousseau.

\section{CONCLUSION}

In fairness to Habermas, it needs to be said that he foresees some of the objections raised in this essay. On several occasions, most copiously in his interviews, he intimated that he personally feels no urge to "bring a 
satisfying order to chaos," that "there is nothing at all to which I have an unambivalent attitude," that rational society must be "as fallibilist and as open to self-correction as possible," that "every intervention in complex social structures has such unforeseeable consequences that processes of reform can only be defended as scrupulous processes of trial and error, under the careful control of those who have to bear their consequences" (Habermas 1986, pp. 126, 144, 187). Such statements qualify only as disclaimers, however, unless they are translated into theoretical terms. In its present form, TCA provides no conceptual room for indeterminacy, has little use for nondiscursiveness, fails to appreciate the critical potential of sentiment, and does not square off discursive ethics with the need for personal responsibility. This is exactly why it is so important for Habermas and pragmatists to continue the search for common ground. The cross-fertilization is likely to be beneficial for both sides.

Pragmatists can learn from Habermas how to grasp in communicationtheoretic terms systemic distortions that delimit access to public discourse. The theory of communicative action offers valuable insights into the discursive bottlenecks that are created in an overloaded market system and that are prone to be exploited by particularistic interests. Habermas has put his finger on an issue that is (or should be) central to the pragmatism-inspired social inquiry: the need to bridge the gap between action-theoretic and system-theoretic languages, between micro- and macrolevel analyses of social processes. Thus TCA provides fresh food for thought on how the movement toward formal representation in democratic systems affects discursive will formation and what can be done to safeguard substantive democracy from the distortions it suffers when responsibility for public affairs is delegated to experts. Finally, Habermas's analysis should help contemporary interactionists to reclaim the critical dimension of early pragmatism and refocus their inquiry on the structural conditions that hamper access to public discourse and undermine the conditions for fruitful dissent.

Habermas and Continental critical theorists have still more to learn from pragmatists. They have yet to acknowledge that reason uncaged is reason enlightened by sentiment, sensitized to uncertainty, steeped in ambivalence, willing to come to terms with common sense, humbled by the consciousness of the limits that nature sets to its ambitions. Emancipated from its bias against indeterminacy, reason is likely to concede that a consensus based on good reasons alone is a poor guide for action and that the ideal speech situation must include among its provisions an agreement to disagree. The question that critical thinkers might want to ponder is how to make our emotions intelligent and our intellect emotion- 
ally sane. In sum, critical theory could greatly benefit from the pragmatist insights into embodied experience and objective uncertainty.

These concerns are consistent with the broadly based trends in modern science, which is increasingly turning its attention toward chaos, uncertainty, fuzzy logic, emergent processes, dissipative structures, and other patently nonclassical subjects. The time has come to reconsider pragmatist philosophy and interactionist sociology (which derived its inspiration from, though has not always been faithful to, pragmatism) with an eye to determining how both have presaged the developments in nonclassical science. ${ }^{11}$ The future agenda includes a sociology in the pragmatist key, the one that eschews both the irrationalism of Lebensphilosophie and the conservative proclivities of postmodernism - a critical social science of uncertainty that combines the commitment to emancipation with the readiness to meet head-on objective uncertainty.

\section{REFERENCES}

Adorno, Theodor W. (1951) 1978. Prisms. London: Neville Spearman. . (1966) 1973. Negative Dialectics. New York: Seabury Press.

1965. "Repressive Tolerance." Pp. 81-118 in Critique of Pure Tolerance. Boston: Beacon Press.

Alexander, Thomas M. 1987. John Dewey's Theory of Art, Experience and Nature: The Horizons of Feeling. Albany: State University of New York Press.

$\rightarrow$ Antonio, Robert J. 1983. "The Origin, Development, and Contemporary Status of Critical Theory." Sociological Quarterly 24:325-51.

- 1989. "The Normative Foundations of Emancipatory Theory: Evolutionary versus Pragmatic Perspectives." American Journal of Sociology 94:721-48.

Benhabib, Seyla. 1987. "The Generalized and the Concrete Other: The KohlbergGilligan Controversy and Feminist Theory." Pp. 77-95 in Feminism as Critique: On the Politics of Gender, edited by Seyla Benhabib. Minneapolis: University of Minnesota Press.

Bernstein, Richard J. 1983. Beyond Objectivism and Relativism: Science, Hermeneutics, Praxis. Philadelphia: University of Pennsylvania Press.

- ed. 1985. Habermas and Modernity. Cambridge, Mass.: MIT Press.

Betz, J. 1974. "George Herbert Mead on Human Rights." Transactions of the Charles S. Peirce Society 10:199-223.

Blumer, Herbert. 1969. Symbolic Interactionism: Perspective and Method. Englewood, N.J.: Prentice-Hall.

Cohen, Ira J. 1985. "The Underemphasis on Democracy in Marx and Weber." Pp. 274-99 in A Weber-Marx Dialogue, edited by Robert J. Antonio and Ronald M. Glassman. Lawrence: University Press of Kansas.

Coughlan, Neil. 1975. Young John Dewey. Chicago: University of Chicago Press.

Dewey, John. (1890) 1969. "The Logic of Verification." Pp. 83-92 in John Dewey, the Early Works. Vol. 3, 1889-1892. Carbondale: Southern Illinois University Press.

${ }^{11}$ See Shalin (1991) on pragmatism and symbolic interactionism as humanistic counterparts of nonclassical science. 


\section{7:127-41.}

\section{- 1916b. Essays in Experimental Logic. New York: Dover.}

. (1916) 1966. Democracy and Education. New York: Macmillan.

- (1920) 1950a. Reconstruction in Philosophy. New York: Mentor.

- (1922) 1950b. Human Nature and Conduct. New York: Modern Library.

ture, edited by Gail Kennedy. Boston: D. C. Heath.

ture, (1927) 1954. The Public and Its Problems. New York: Henry Holt.

- (1929) 1958a. Experience and Nature. New York: Dover.

- (1934) 1958b. Art and Experience. New York: G. P. Putnam's Sons.

-1938. Logic: The Theory of Inquiry. New York: Henry Holt.

- 1939. Freedom and Culture. New York: Capricorn.

. 1946. The Problems of Men. New York: Philosophical Library.

Dewey, John, and James H. Tufts. (1908) 1976. Ethics. Vol. 5 in John Dewey: The Middle Works, 1899-1924. Carbondale: Southern Illinois University Press.

Dewey, John, and John L. Childs. 1933. "The Underlying Philosophy of Education." Pp. 287-319 in The Educational Frontier, edited by W. H. Kilpatrick. New York: Appleton-Century.

Deegan, M. J., and J. S. Burger. 1978. "George Herbert Mead and Social Reform: His Work and Writings." Journal of the History of the Behavioral Sciences 14:362-73.

Diner, S. J. 1980. A City and Its Universities: Public Policy in Chicago, 1892-1919. Chapel Hill: University of North Carolina Press.

Faris, Robert E. 1970. Chicago Sociology, 1920-1932. Chicago: University of Chicago Press.

Ferrara, Allesandro. 1985. "A Critique of Habermas' Diskursetik." Telos 64:45-74.

Fichte, J. G. [1794] 1970. The Science of Knowledge. New York: Appleton-CenturyCrofts.

Forester, John, ed. 1985. Critical Theory and Public Life. Cambridge, Mass.: MIT Press.

Gadamer, Hans-Georg. 1977. "On the Scope and Function of Hermeneutical Reflection." Pp. 18-58 in Philosophical Hermeneutics. Berkeley: University of California Press.

Giddens, Anthony. 1972. Politics and Sociology in the Works of Max Weber. London: Macmillan.

Geuss, Raymond. 1981. The Idea of a Critical Theory. New York: Cambridge University Press.

Gouinlock, James. 1972. John Dewey's Theory of Value. New York: Humanities Press.

Habermas, Jürgen. [1962] 1989. The Structural Transformation of the Public Sphere: An Inquiry into a Category of Bourgeois Society. Cambridge, Mass.: MIT Press.

. 1970. Toward a Rational Society. Boston: Beacon.

- 1971. Knowledge and Human Interest. Boston: Beacon.

- 1973. Theory and Practice. Boston: Beacon.

- 1975. Legitimation Crisis. Boston: Beacon.

- 1979. Communication and Evolution of Society. Boston: Beacon.

- 1984. The Theory of Communicative Action. Vol. 1, Reason and the Realization of Society. Boston: Beacon.

. 1985. "Questions and Counter Questions." Pp. 192-216 in Habermas and Modernity, edited by Richard J. Bernstein. Cambridge, Mass.: MIT Press.

York: Verso.

York: Verso.
Press. 
1987b. The Theory of Communicative Action. Vol. 2, Life World and System: A Critique of Functionalist Reason. Boston: Beacon.

Hegel, G. W. F. (1807) 1967. The Phenomenology of Mind. New York: Harper \& Row.

(1817) 1975. Hegel's Logic: Being Part of the Encyclopedia of the Philosophical Sciences. London: Oxford University Press.

Held, David. 1980. Introduction to Critical Theory. Berkeley and Los Angeles: University of California Press.

Horkheimer, Max. 1937. "Der Neusten Angriff auf die Metaphysik." Zeitschrift fur Sozialforschung 6:4-53.

- (1937) 1976. "Traditional and Critical Theory." Pp. 206-24 in Critical Sociology, edited by Paul Connerton. New York: Penguin.

- 1947. Eclipse of Reason. New York: Oxford University Press.

1978. Dawn and Decline: Notes, 1926-1931 and 1950-1969. New York: Seabury.

Horkheimer, Max, and Theodor W. Adorno. (1944) 1989. The Dialectics of Enlightenment. New York: Continuum.

James, William. (1897) 1956. The Will to Believe. New York: Dover. . (1909) 1967. Essays in Radical Empiricism and Pluralistic Universe. Gloucester: David McKay.

Jay, Martin. 1973. The Dialectical Imagination. Boston: Little, Brown.

Joas, Hans. 1985. G. H. Mead: A Contemporary Reexamination of His Thought. Cambridge: Polity.

Kant, Immanuel. (1781) 1966. Critique of Pure Reason. New York: Anchor Books. . (1783) 1950. Prolegomena to Any Future Metaphysics. Indianapolis, Ind.: Bobbs-Merrill.

. (1803) 1904. "Lecture Notes on Pedagogy." Pp. 101-222 in The Educational Theory of Immanuel Kant, edited by E. F. Buchner. Philadelphia: Lippincott.

Kellner, Douglas. 1985. "Critical Theory, Max Weber, and the Dialectics of Domination." Pp. 89-116 in A Weber-Marx Dialogue, edited by Robert J. Antonio and Ronald M. Glassman. Lawrence: University Press of Kansas.

Kloppenberg, James T. 1986. Uncertain Victory: Social Democracy and Progressivism in European and American Thought, 1870-1920. New York: Oxford University Press.

McCarthy, Thomas. 1978. The Critical Theory of Jürgen Habermas. Cambridge, Mass.: MIT Press.

Marcuse, Herbert. (1934) 1968a. "The Struggle against Liberalism in the Totalitarian View of the State." Pp. 3-42 in Negations: Essays in Critical Theory. Boston: Beacon.

- (1937) 1968b. "Philosophy and Critical Theory." Pp. 134-58 in Negations: Essays in Critical Theory. Boston: Beacon.

- 1939/1940. "Review of John Dewey's Logic: The Theory of Inquiry." Zeitschrift fur Sozialforschung 9:144-48. Press.

. 1960. Reason and Revolution: Hegel and the Rise of Social Theory. Boston: Beacon.

- 1964. One-Dimensional Man. Boston: Beacon.

1965. "Repressive Tolerance." Pp. 81-118 in A Critique of Pure Tolerance, edited by Robert Paul Wolff, Barrington Moore, Jr., and Herbert Marcuse. Boston: Beacon.

(1968) 1976. "Postscript 1968." Pp. 325-29 in Critical Sociology, edited by Paul Connerton. Harmondsworth: Penguin. 


\section{American Journal of Sociology}

Marx, Karl. (1843) 1971. "A Correspondence of 1843." Pp. 79-82 in Karl Marx: Early Texts. New York: Harper \& Row.

- (1843) 1972. "Letter to Arnold Ruge, September 1843." Pp. 7-10 in The Marx-Engels Reader, edited by Robert C. Tucker. New York: Norton.

. (1846) 1963. The German Ideology, pts. 1, 2. New York: International Publishers.

Mead, George H. (n.d.). George Herbert Mead Papers. University of Chicago Archives, Joseph Regenstein Library.

. 1899. "The Working Hypothesis in Social Reform." American Journal of Sociology 5:367-71.

. (1915) 1964. "Natural Rights and the Theory of the Political Institution."

Pp. 150-70 in Selected Writings: George Herbert Mead, edited by A. J. Reck. New York: Bobbs-Merrill.

. (1927) 1964. "The Objective Reality of Perspectives." Pp. 306-19 in Selected

Writings: George Herbert Mead, edited by A. J. Reck. New York: Bobbs-Merrill.

- (1930) 1964. "Philanthropy from the Point of View of Ethics." Pp. 392-407

in Selected Writings: George Herbert Mead, edited by A. J. Reck. New York: Bobbs-Merrill.

1934. Mind, Self and Society. Chicago: University of Chicago Press.

1936. Movements of Thought in the Nineteenth Century. Chicago: University of Chicago Press.

1938. The Philosophy of the Act. Chicago: University of Chicago Press.

Mommsen, Wolfgang J. 1974. The Age of Bureaucracy: Perspectives on the Political Sociology of Max Weber. New York: Harper.

Mumford, Lewis. 1967. The Myth of the Machine: Techniques and Human Development. New York: Harcourt, Brace, Jovanovich.

Neumann, Franz L. 1953. The Cultural Migration: The European Scholar in America. Crawford: University of Pennsylvania Press.

O'Neill, J. 1985. "Decolonization and the Ideal Speech Community." Pp. 57-76 in Critical Theory and Public Life, edited by John Forester. Cambridge, Mass.: MIT Press.

Peirce, Charles S. 1976. The New Elements of Mathematics. Atlantic Highlands, N.J.: Humanities Press.

Przeworski, Adam. 1986. Capitalism and Social Democracy: Studies in Marxist Social Theory. Cambridge: Cambridge University Press.

Rochberg-Halton, Eugine. 1986. Meaning and Modernity: Social Theory in the Pragmatic Attitude. Chicago: University of Chicago Press.

Rorty, Richard. 1979. Philosophy and the Mirror of Nature. Princeton, N.J.: Princeton University Press. Press.

1985. "Habermas and Lyotard on Postmodernity." Pp. 161-75 in Habermas and Modernity, edited by Richard J. Bernstein. Cambridge: Mass.: MIT Press.

. 1987. "Science as Solidarity." Pp. 38-52 in The Rhetoric of the Human Sciences, edited by John S. Nelson, Allan Megill, and Donald N. McClosckey. Madison: University of Wisconsin Press.

. 1989. Contingency, Irony, and Solidarity. Cambridge: Cambridge University Press.

Rose, Gillian. 1978. The Melancholy Science: An Introduction to the Thought of Theodor W. Adorno. New York: Columbia University Press.

Rosenthal, Sandra. 1986. Speculative Pragmatism. Amherst, Mass.: MIT Press.

Royce, Josiah. 1919. Lectures on Modern Idealism. New Haven, Conn.: Yale University Press. 


\section{Critical Theory}

Schelling, F. W. J. [1800] 1978. The System of Transcendental Idealism. Charlottesville: University of Virginia Press.

$\rightarrow$ Shalin, D. N. 1984. "The Romantic Antecedents of Meadian Social Psychology." Symbolic Interaction 7:43-65.

1986a. "Pragmatism and Social Interactionism." American Sociological Review 51:9-29.

1986b. "Romanticism and the Rise of Sociological Hermeneutics." Social Research 53:77-123.

1988. "G. H. Mead, Socialism, and the Progressive Agenda." American Journal of Sociology 93:913-51.

1990. "The Impact of Transcendental Idealism on Early German and American Sociology." Current Perspectives in Social Theory 10:1-29.

1991. "The Pragmatic Origins of Symbolic Interactionism and the Crisis of Classical Science." Studies in Symbolic Interaction 12:223-51.

— ed. 1992. "Habermas, Pragmatism, and Critical Theory." Symbolic Interaction 15 (Fall). In press.

Scheler, Max. [1926] 1977. Erkentnis und Arbeit: Eine Studie uber Wert und Grenzen des pragmatischen Motivs in der Erkentnis der Welt. Frankfurt am Main.

Schumpeter, J. A. 1950. Capitalism, Socialism and Democracy. New York: Harper \& Row.

Sciulli, David. 1988. "Foundations of Societal Constitutionalism: Principles from the Concepts of Communicative Action and Procedural Legality." British Journal of Sociology 39:377-407.

1992. "Habermas, Critical Theory, and the Relativistic Predicament." Symbolic Interaction 15 (Fall). In press.

Thompson, John B., and David Held, eds. 1982. Habermas: Critical Debates. Cambridge, Mass.: MIT Press.

Van den Berg, Axel. 1990. "Habermas and Modernity: A Critique of the Theory of Communicative Action." Current Perspectives in Social Theory 10:161-94.

Weber, Max. 1964. The Theory of Social and Economic Organization. New York: Free Press.

[1904-5] 1958. The Protestant Ethic and the Spirit of Capitalism. New York: Scribner's Sons.

Wolin, Richard. 1987. "Critical Theory and the Dialectics of Rationalism." New German Critique 41:23-52. 